\title{
16. NEOGENE CALCAREOUS NANNOFOSSILS FROM ODP LEG 105: IMPLICATIONS FOR PLEISTOCENE PALEOCEANOGRAPHIC TRENDS ${ }^{1}$
}

\author{
Stephen Knüttel, ${ }^{2}$ Merlin D. Russell, Jr., ${ }^{2}$ and John V. Firth ${ }^{2}$
}

\begin{abstract}
Neogene calcareous nannofossils were examined from 10 holes at three sites cored during ODP Leg 105. Sediment recovered in Baffin Bay at Site 645 is virtually barren of calcareous nannofossils, with the exception of a sparse lower Miocene assemblage. Sites 646 and 647 in the Labrador Sea contain upper Miocene to Holocene sediments having numerous barren intervals.

Upper Pleistocene fossil coccolithophorid floras in the Labrador Sea indicate alternations of cold subpolar with transitional (subpolar/subtropical) assemblages. Extreme variations in the abundance of Coccolithus pelagicus were observed at Sites 646 and 647 . These variations are correlated with stable isotopic data to interpret oceanographic responses to warming and cooling trends. The climatic history indicated by the changes of these assemblages closely approximates the past climatic fluctuations recorded in other North Atlantic cores.

One new taxon, Discoaster bergenii, is described.
\end{abstract}

\section{INTRODUCTION}

Sites 645,646 , and 647 were drilled along a north-south transect from Baffin Bay to the Labrador Sea during September and October of 1985 (Fig. 1). These two small ocean basins are of geologic interest because of their confinement between the continental crust of Greenland and Canada and because of their high-latitude position. Today, these basins serve as a conduit for the exchange of water masses between the Arctic and North Atlantic oceans. Calcareous nannofossil assemblages associated with migrations of surface-water masses have left their record within the underlying oceanic sediments at these sites. Thus, the relationships among the different assemblages within the sedimentary column are useful for interpreting oceanic responses to past climatic events.

Three of the four characteristic nannofossil assemblages defined in the North Atlantic by McIntyre et al. (1972) are predominant within sediments at these sites. These three fossil floras include a cold subpolar assemblage, a warm subpolar assemblage, and a transitional (subpolar/subtropical) assemblage. Particular attention has been paid to interpreting these assemblages and their possible correlation with migrations of warmer surface-water masses within the area.

Of the 11 holes cored during Leg 105, 10 were examined for contents of calcareous nannofossils. Most samples examined from six holes at Site 645 (Baffin Bay) are barren of calcareous nannofossils. However, lower Miocene calcareous nannofossils can be seen in the bottom part of Hole 645E.

Two holes were cored at Site 646 (Labrador Sea); Hole 646A contains an upper Pleistocene through Holocene interval, and Hole 646B contains an upper Miocene through upper Pleistocene sequence. Alternations of cold subpolar assemblages with cool transitional (subpolar/subtropical) assemblages in sediments are best developed in the upper Pleistocene at this site.

Of the two holes cored at Site 647, Hole 647A was examined in detail. Samples from Cores 105-647B-2H, 105-647B-3H, and $105-647 \mathrm{~B}-4 \mathrm{H}$ also were examined to cover the coring gap present in Hole 647A (Core 105-647A-3R). Although Hole 647A bot-

\footnotetext{
${ }^{1}$ Srivastava, S. P., Arthur, M., Clement, B., et al., 1989. Proc. ODP, Sci. Results, 105: College Station, TX (Ocean Drilling Program).

2 Department of Geology, Florida State University, Tallahassee, FL 32306.
}

tomed out in the lower Eocene, it contains an upper Pliocene through Holocene section and only a small 3-m interval of upper Miocene sediment present at 116 meters below sea floor (mbsf).

\section{METHODS}

All slides used here were prepared from raw sediment. Sediment was distributed as uniformly as possible to allow accurate abundance estimates. Smear slides were made using Norland 61 optical adhesive as a mounting medium and were examined in the light microscope. Approximately two traverses were made across the slide at $500 \times$ magnification. Pleistocene materials were examined at $1250 \times$ magnification, and the abundances adjusted accordingly.

Estimates of abundance for individual species of nannofossils at $500 \times$ magnification are as follows:

$$
\begin{aligned}
& \mathrm{V}=\text { very abundant; } 100+\text { specimens per field of view; } \\
& \mathrm{A}=\text { abundant; } 11 \text { to } 100 \text { specimens per field of view; } \\
& \mathrm{C}=\text { common; } 1 \text { to } 10 \text { specimens per field of view; } \\
& \mathrm{F}=\text { few; } 1 \text { specimen per } 2 \text { to } 10 \text { fields of view; } \\
& \mathrm{R}=\text { rare; } 1 \text { specimen per } 11 \text { to } 50 \text { fields of view; } \\
& \mathrm{P}=\text { present; } 1 \text { specimen per } 50 \text { or more fields of view; } \\
& \mathrm{B}=\text { barren; no nannofossils observed on the slide. }
\end{aligned}
$$

The abundance of the total calcareous nannofossil population also was estimated using this scale. Lowercase letters were not used to indicate reworked taxa because in some cases the amount of reworked material was uncertain, and different conclusions can be drawn from the data presented.

Preservation of calcareous nannofossils in each sample was recorded as follows:

$$
\begin{aligned}
\mathrm{G}=\text { good; specimens show little effects of overgrowth and/or } \\
\text { dissolution; }
\end{aligned}
$$

$\mathrm{M}=$ moderate; specimens show some effects of overgrowth and/or dissolution; identification of taxa is sometimes impaired;

$\mathrm{P}=$ poor; specimens show effects of advanced overgrowth and/ or dissolution; most taxa can only be questionably identified.

The actual number of the individuals of Coccolithus pelagicus observed in selected samples was counted to record changes in population abundance through time. The number of specimens per field of view was counted in 100 fields (approximately one-half traverse across each slide) at $1250 \times$ magnification. 


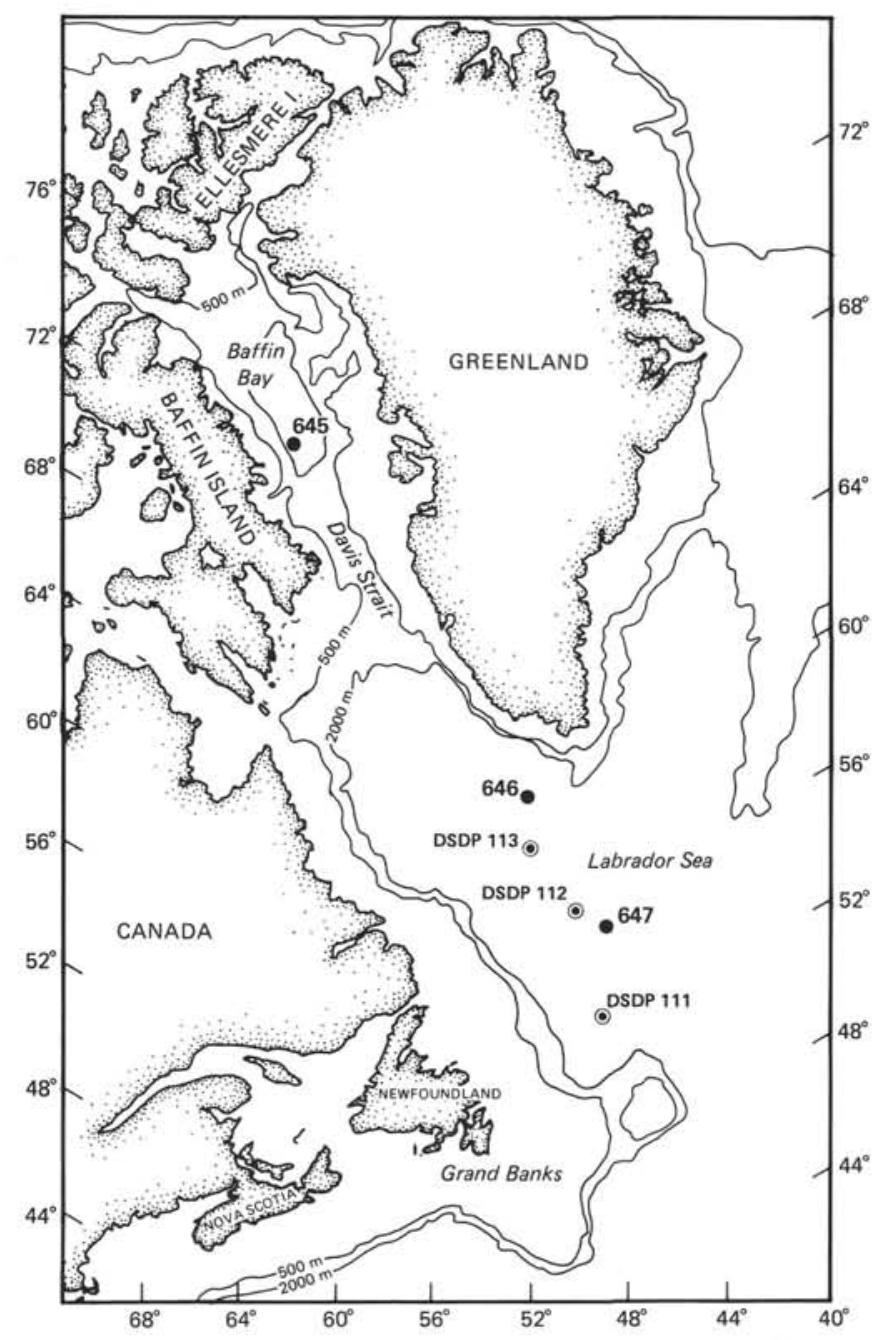

Figure 1. Location map for ODP Leg 105 sites cored in Baffin Bay and the Labrador Sea.

Slides with lower numbers of $C$. pelagicus were also counted at $500 \times$ magnification to confirm the results obtained at $1250 \times$ magnification.

Because of the preliminary nature of this study and the relatively coarse sampling intervals, we did not employ quantitative analyses. A more detailed study will be required to verify and quantify more precisely the changes in the $C$. pelagicus population throughout time.

The taxa considered here are listed in Appendix A, and the systematic paleontology for the new taxon is presented in Appendix B.

\section{BIOSTRATIGRAPHY AND ZONATION}

The zonation used here to assign age is the standard scheme of Martini and Müller (1986). The absolute ages and epoch and stage boundaries are taken from Berggren et al. (1985). The delineation of the Pliocene/Pleistocene boundary is approximated here by the extinction of Calcidiscus macintyrei (Backman et al., 1983). Backman and Shackleton (1983) placed an estimated age for the extinction of $C$. macintyrei at $1.45 \mathrm{Ma}$. Note that this datum occurs slightly above the Pliocene/Pleistocene boundary.

\section{Site 645}

Site 645 is located near the western margin of southern Baffin Bay at $70^{\circ} 27.49^{\prime} \mathrm{N}$ and $64^{\circ} 39.26^{\prime} \mathrm{W}$, at a water depth of
2018 mbsf. Seven holes were drilled at this site with a total penetration depth of $1147.1 \mathrm{mbsf}$ and an average recovery of $66 \%$ for all holes. Hole $645 \mathrm{~A}$ consisted of one core $4.9 \mathrm{~m}$ long, which was not examined for nannofossils.

Only 26 samples from Holes 645B, 645C, 645D, 645E, 645F, and $645 \mathrm{G}$ were found to contain nannofossils. In most samples, the nannofossils are very rare and consist of one or two longranging species (Coccolithus pelagicus and small Reticulofenestra spp.). Two intervals (the "Interval with Reticulofenestra pseudoumbilica" and "Interval with Helicosphaera ampliaperta") were recognized. These intervals can be correlated with the calcareous nannofossil intervals defined by Müller (1976) for the Norwegian-Greenland Sea.

The presence of Gephyrocapsa spp. in Sections 105-645B$1 \mathrm{X}, \mathrm{CC}$ and 105-645B-8X, CC indicates that these two samples are Pliocene or younger in age.

Rare Reticulofenestra pseudoumbilica and Coccolithus pelagicus occur sporadically from Section 105-645E-35R, CC to Sample $105-645 \mathrm{E}-70 \mathrm{R}-2,42-44 \mathrm{~cm}$. In addition, the latter sample contains specimens of Helicosphaera sp., Reticulofenestra spp. (small), Braarudosphaera bigelowii, and Pontosphaera sp. This interval correlated with the "Interval with Reticulofenestra pseudoumbilica" (Müller, 1976), which corresponds to the combined Zones NN5 to NN15 (Martini, 1971). Thus, Section 105-645E35 R, CC through Sample 105-645E-70R-2, 42-44 cm, have been assigned a middle Miocene to early Pliocene age.

Samples 105-645E-70R-5, 61-63 cm, 105-645E-70R, CC, 105645E-71R-2, 40-42 cm, and 105-645E-71R-3, 39-41 cm, contain an assemblage similar to that of Sample 105-645E-70R-2, 42-44 $\mathrm{cm}$, but also contain Helicosphaera ampliaperta. These samples can be correlated with the "Interval with Helicosphaera ampliaperta" (Müller, 1976), which approximates Zones NN3 to NN4 (Martini, 1971). However, Bramlette and Wilcoxon (1967) recorded the lowest occurrence of $H$. ampliaperta in Trinidad near the Oligocene/Miocene boundary (base of the Discoaster druggii Zone). Therefore, a more conservative estimate of the zonal assignment for Samples 105-645E-70R-5, 61-63 cm, to 105-645E$71 \mathrm{R}-3,39-41 \mathrm{~cm}$, should be from Zone NN2 to NN4, within the lower Miocene.

Section 105-645E-73R, CC contains an assemblage similar to those in the "Interval with $H$. ampliaperta," but lacks $H$. ampliaperta. We are not sure whether this sample lies below the lowest occurrence of $H$. ampliaperta or whether $H$. ampliaperta is absent because of environmental changes. No Oligocene species are present in this sample, which suggests a Miocene age.

\section{Site 646}

Site 646 is located in the Labrador Sea approximately $500 \mathrm{~km}$ southwest of the southernmost point of Greenland at $58^{\circ} 12.56^{\prime} \mathrm{N}$ and $48^{\circ} 22.15^{\prime} \mathrm{W}$. Two holes, $646 \mathrm{~A}$ and $646 \mathrm{~B}$, were cored at this site at a water depth of 3450 mbsf. Hole 646A was cored with the advanced hydraulic piston corer (APC) to a depth of 103.5 mbsf and yielded 11 cores containing a total of $90.4 \mathrm{~m}$ of upper Pleistocene to Holocene sediments. The use of this coring system provided relatively undisturbed sediments that are well suited for the detailed study of calcareous nannofossil assemblages through time. Hole 646B was cored by a combination of APC (Cores 105-646B-1H through 105-646B-14H) and extended-core barrel (XCB; Cores 105-646B-15X through 105-646B-80X). Hole 646B was completed to a depth of $766.7 \mathrm{mbsf}$ and yielded $404.5 \mathrm{~m}$ of upper Miocene to Holocene sediments.

\section{Hole $646 \mathrm{~A}$}

Total sediment recovered from Hole 646A can be placed within lithologic Subunit IA (see Site 646 chapter, Srivastava, Arthur, et al., 1987) and is characterized by terrigenous silty and clayey sediments (Fig. 2). Nannofossil abundance in these sediments varies dramatically throughout the hole-from samples 
A

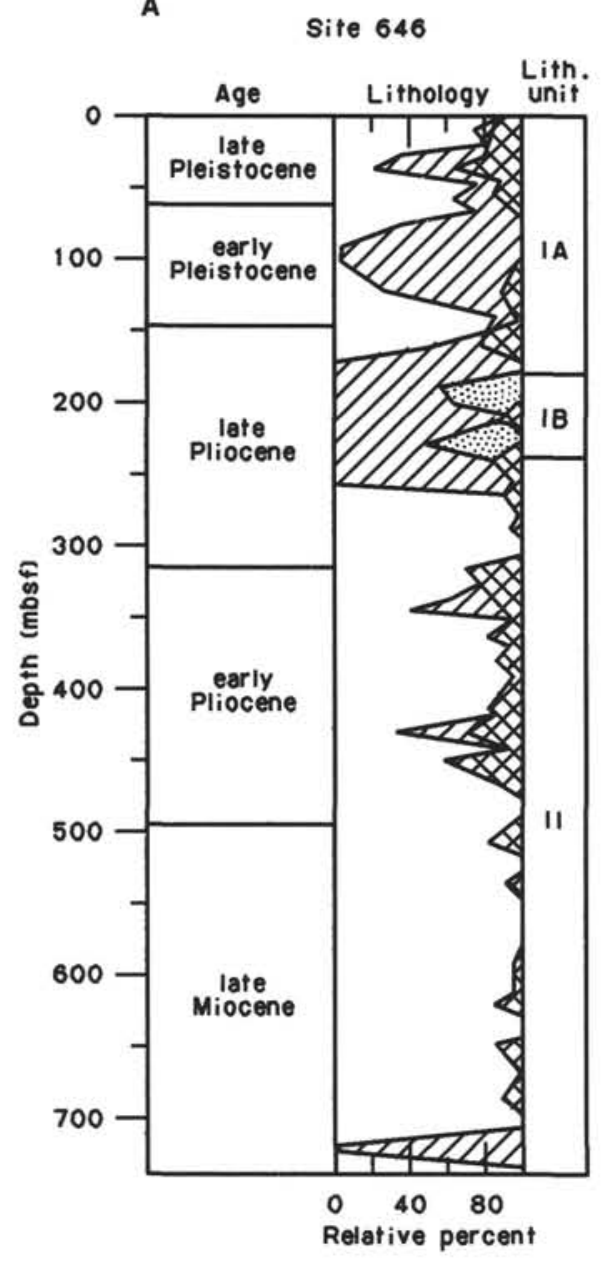

B

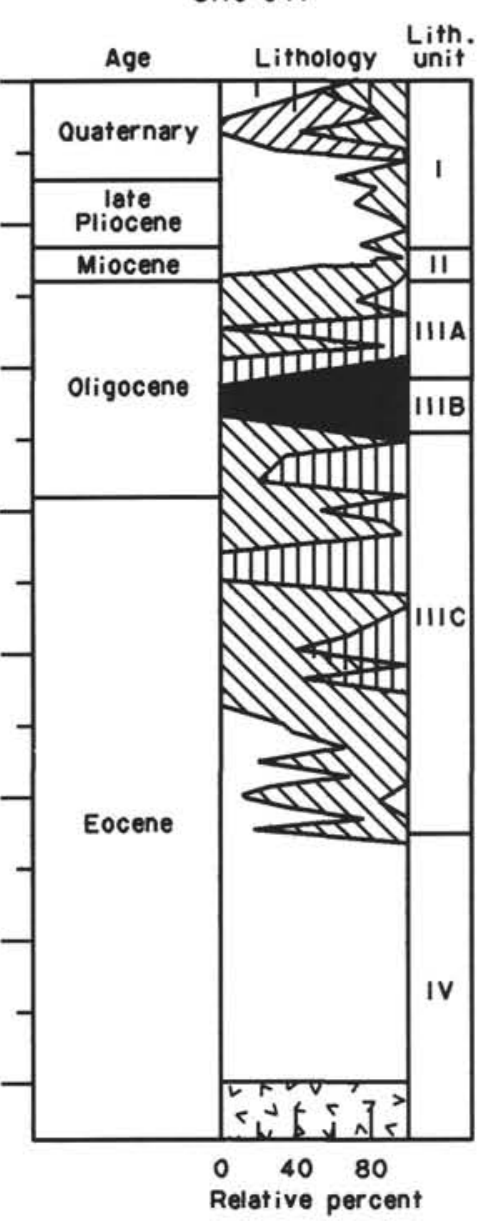

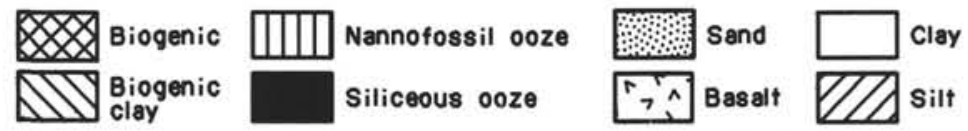

Figure 2. A. Lithologic section of Site 646. B. Lithologic section of Site 647.

that are barren of calcareous nannofossils to those that contain abundant nannofossils (Table 1).

Diversity within the nannofossil population is low; only seven species form the majority of the subpolar assemblages. These include Emiliania huxleyi (age dependant), Gephyrocapsa oceanica, Gephyrocapsa spp. (small), Calcidiscus leptoporus, Coccolithus pelagicus, Pseudoemiliania lacunosa (age dependant), and Reticulofenestra spp. (small). Additional species more characteristic of the transitional assemblage include Helicosphaera carteri, Syracosphaera pulchra, Pontosphaera spp., Umbilicosphaera mirabilis, U. angustiforamen, U. cricotus, Rhabdosphaera clavigera, Helicosphaera inversa, Scapholithus fossilis, and Ceratolithus cristatus.

In subpolar nannofossil floras, Emiliania huxleyi, Gephyrocapsa spp., Reticulofenestra spp. (small), and Coccolithus pelagicus dominate the assemblage in most samples. Within the upper part of the interval (above Section 105-646A-3H, CC), in samples where $C$. pelagicus is abundant, other species are lower in numbers. The opposite is true for samples where Emiliania huxleyi, Gephyrocapsa spp., and Reticulofenestra spp. (small) dominate the assemblage. Samples examined below Section 105$646 \mathrm{~A}-3 \mathrm{H}, \mathrm{CC}$, contain assemblages with higher numbers of $\mathrm{Ge}$ - phyrocapsa spp., Reticulofenestra spp. (small), and Coccolithus pelagicus interlayered with samples that are generally lower in overall numbers of nannofossils. The fluctuations suggest cooling and warming trends. Particular attention has been given to these changes for possible interpretation of the glacial history of the area. These relationships are discussed later.

The oldest sediment in Hole 646A can be placed in Subzone NN19b of the upper Pleistocene Pseudoemiliania lacunosa Zone (NN19). Calcidiscus macintyrei was not observed in the lowest sample examined; thus, we assume that all sediment was deposited after the extinction of this species. This indicates a maximum age of less than 1.45 Ma (Backman and Shackleton, 1983), and all samples between the bottom of the hole (Section 105$646 \mathrm{~A}-11 \mathrm{H}, \mathrm{CC})$ up to and including Sample 105-646A-4H-6, $96-98 \mathrm{~cm}$, are assigned to Subzone NN19b. Preservation and abundance vary greatly within the subzone, and numerous intervals barren of calcareous nannofossils are present. However, these barren intervals are restricted to the lower part of the hole (below Sample 105-646A-4H-6, 110-112 cm). Preservation is generally poorer in samples with lower numbers of nannofossils than in those with more numerous specimens. The dominant mode of secondary alteration is from dissolution. For the most 
Table 1. Distribution of Pleistocene calcareous nannofossils in Hole 646A.

\begin{tabular}{|c|c|c|c|c|c|c|c|c|c|c|c|c|c|c|c|}
\hline Age & $\begin{array}{c}\text { Zone } \\
\text { (After Martini } \\
\text { and Muller, } \\
\text { 1986) }\end{array}$ & $\begin{array}{c}\text { Sample } \\
\text { interval } \\
(\mathrm{cm})\end{array}$ & 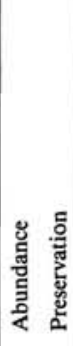 & 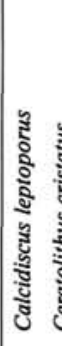 & 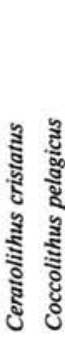 & 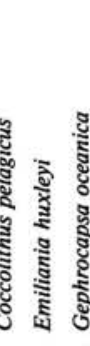 & & 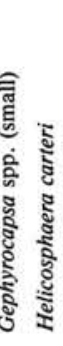 & 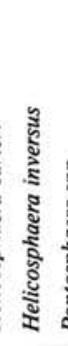 & 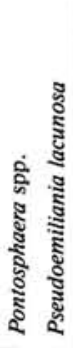 & 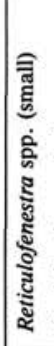 & 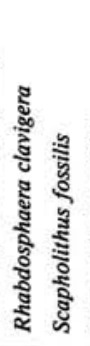 & 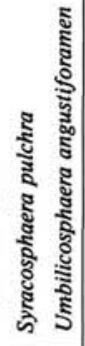 & 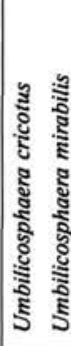 & \\
\hline \multirow[b]{3}{*}{ Pleistocene } & $\mathrm{NN} 21$ & $\begin{array}{c}105-646 \mathrm{~A}-1 \mathrm{H}-1,48-50 \\
1 \mathrm{H}-2,48-50 \\
1 \mathrm{H}, \mathrm{CC} \\
2 \mathrm{H}-1,102-104 \\
2 \mathrm{H}-2,102-104 \\
2 \mathrm{H}-3,102-104 \\
2 \mathrm{H}-4,102-104 \\
2 \mathrm{H}-5,102-104 \\
\end{array}$ & $\begin{array}{ll}\mathrm{V} & \mathrm{G} \\
\mathrm{A} & \mathrm{M} \\
\mathrm{V} & \mathrm{G} \\
\mathrm{V} & \mathrm{G} \\
\mathrm{A} & \mathrm{M} \\
\mathrm{A} & \mathrm{M} \\
\mathrm{C} & \mathrm{M} \\
\mathrm{A} & \mathrm{M} \\
\end{array}$ & $\begin{array}{l}\mathrm{F} \\
\mathrm{F} \\
\mathrm{C} \\
\mathrm{A} \\
\mathrm{F} \\
\mathrm{C} \\
\mathrm{C} \\
\mathrm{A} \\
\end{array}$ & $\begin{array}{ll} & \mathrm{V} \\
\mathrm{F} \\
\mathrm{C} \\
\mathrm{P} \\
\mathrm{F} \\
\mathrm{C} \\
\mathrm{F} \\
\mathrm{F} \\
\mathrm{F}\end{array}$ & 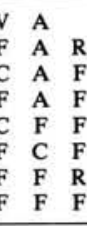 & 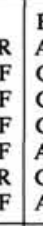 & $\begin{array}{ll}\mathrm{F} & \mathrm{F} \\
\mathrm{A} & \mathrm{R} \\
\mathrm{C} & \mathrm{F} \\
\mathrm{C} & \mathrm{A} \\
\mathrm{C} & \mathrm{R} \\
\mathrm{A} & \mathrm{C} \\
\mathrm{C} & \mathrm{F} \\
\mathrm{A} & \mathrm{F}\end{array}$ & $\mathrm{R}$ & $\begin{array}{l}\mathrm{R} \\
\mathrm{P} \\
\mathrm{R}\end{array}$ & $\begin{array}{l}\mathrm{F} \\
\mathrm{C} \\
\mathrm{C} \\
\mathrm{A} \\
\mathrm{C} \\
\mathrm{A} \\
\mathrm{C} \\
\mathrm{A}\end{array}$ & $\begin{array}{l}\text { P } \\
\text { P P }\end{array}$ & $\begin{array}{ll}\mathrm{F} & \mathrm{R} \\
\mathrm{P} & \mathrm{R} \\
\mathrm{P} & \mathrm{P} \\
\mathrm{P} & \mathrm{R} \\
& \mathrm{P} \\
\mathrm{P} & \\
& \\
\mathrm{F} & \\
\end{array}$ & $\begin{array}{ll}\mathrm{P} & \mathrm{R} \\
\mathrm{P} \\
\mathrm{R} \\
\mathrm{R} \\
\mathrm{P} \\
\mathrm{P} \\
\mathrm{R}\end{array}$ & $\begin{array}{l}\mathrm{R} \\
\mathrm{R} \\
\mathrm{R} \\
\mathrm{P} \\
\mathrm{R} \\
\end{array}$ \\
\hline & NN20 & $\begin{array}{l}2 \mathrm{H}-6,104-106 \\
2 \mathrm{H}, \mathrm{CC} \\
3 \mathrm{H}-1,80-82 \\
3 \mathrm{H}-2,80-82 \\
3 \mathrm{H}-3,80-82 \\
3 \mathrm{H}-4,80-82 \\
3 \mathrm{H}-5,80-82 \\
3 \mathrm{H}, \mathrm{CC} \\
4 \mathrm{H}-1,96-98 \\
4 \mathrm{H}-2,96-98 \\
4 \mathrm{H}-3,96-98 \\
4 \mathrm{H}-4,96-98 \\
4 \mathrm{H}-5,96-98\end{array}$ & \begin{tabular}{|ll} 
R & P \\
C & $M$ \\
A & $M$ \\
A & $M$ \\
A & G \\
A & M \\
A & M \\
B & \\
V & G \\
V & M \\
V & G \\
V & G \\
C & M \\
\end{tabular} & \begin{tabular}{|l}
$\mathrm{P}$ \\
$\mathrm{F}$ \\
$\mathrm{A}$ \\
$\mathrm{C}$ \\
$\mathrm{F}$ \\
$\mathrm{R}$ \\
$\mathrm{C}$ \\
$\mathrm{C}$ \\
$\mathrm{F}$ \\
$\mathrm{C}$ \\
$\mathrm{C}$ \\
$\mathrm{R}$ \\
\end{tabular} & $\begin{array}{l}\mathrm{F} \\
\mathrm{C} \\
\mathrm{C} \\
\mathrm{A} \\
\mathrm{F} \\
\mathrm{C} \\
\mathrm{A} \\
\mathrm{A} \\
\mathrm{A} \\
\mathrm{A} \\
\mathrm{R} \\
\end{array}$ & $\begin{array}{ll}\mathrm{F} & \mathrm{R} \\
\mathrm{F} & \mathrm{F} \\
\mathrm{H} & \mathrm{F} \\
\mathrm{F} \\
\mathrm{F} \\
\mathrm{F} \\
\mathrm{F} \\
\mathrm{C} \\
\mathrm{F} \\
\mathrm{F} \\
\mathrm{F}\end{array}$ & \begin{tabular}{l|l} 
& $F$ \\
$\mathrm{R}$ & $\mathrm{F}$ \\
$\mathrm{F}$ & $\mathrm{C}$ \\
$\mathrm{F}$ & $\mathrm{C}$ \\
$\mathrm{R}$ & $\mathrm{C}$ \\
$\mathrm{F}$ & $A$ \\
$\mathrm{~F}$ & $\mathrm{~A}$ \\
$\mathrm{C}$ & $\mathrm{A}$ \\
$\mathrm{F}$ & $\mathrm{V}$ \\
$\mathrm{F}$ & $\mathrm{I}$ \\
& $C$
\end{tabular} & $\begin{array}{ll}\mathrm{P} & \\
\mathrm{F} & \mathrm{F} \\
\mathrm{C} & \mathrm{F} \\
\mathrm{C} & \mathrm{F} \\
\mathrm{C} & \mathrm{F} \\
\mathrm{C} & \mathrm{R} \\
\mathrm{A} & \mathrm{R} \\
& \\
\mathrm{A} & \mathrm{F} \\
\mathrm{A} & \mathrm{F} \\
\mathrm{V} & \mathrm{F} \\
\mathrm{V} & \mathrm{R} \\
\mathrm{C} & \\
\end{array}$ & $\begin{array}{l}\mathrm{R} \\
\mathrm{P} \\
\mathrm{R} \\
\mathrm{P}\end{array}$ & $\begin{array}{l}\mathbf{R} \\
\mathrm{P}\end{array}$ & $\begin{array}{l}\mathrm{R} \\
\mathrm{C} \\
\mathrm{C} \\
\mathrm{C} \\
\mathrm{A} \\
\mathrm{C} \\
\mathrm{A} \\
\mathrm{A} \\
\mathrm{A} \\
\mathrm{A} \\
\mathrm{A} \\
\mathrm{C} \\
\end{array}$ & $\begin{array}{ll} & \\
P & P \\
P & \end{array}$ & $\begin{array}{ll}\mathrm{R} & \\
\mathrm{R} & \\
\mathrm{P} & \mathrm{P} \\
\mathrm{R} & \mathrm{R} \\
& \\
\mathrm{R} & \mathrm{P} \\
\mathrm{R} & \mathrm{R} \\
\mathrm{R} & \mathrm{R} \\
\mathrm{R} & \mathrm{P} \\
\mathrm{R} & \end{array}$ & $P^{P}$ & $\mathbf{P}$ \\
\hline & NN19b & $\begin{array}{l}4 \mathrm{H}-6,96-98 \\
4 \mathrm{H}, \mathrm{CC} \\
5 \mathrm{H}-1,104-106 \\
5 \mathrm{H}-2,104-106 \\
5 \mathrm{H}-3,104-106 \\
5 \mathrm{H}-4,104-106 \\
5 \mathrm{H}-5,104-106 \\
5 \mathrm{H}-6,104-106 \\
5 \mathrm{H}, \mathrm{CC} \\
6 \mathrm{H}-1,110-112 \\
6 \mathrm{H}-2,110-112 \\
6 \mathrm{H}-3,110-112 \\
6 \mathrm{H}-4,110-112 \\
6 \mathrm{H}-5,110-112 \\
6 \mathrm{H}-6,110-112 \\
6 \mathrm{H}, \mathrm{CC} \\
7 \mathrm{H}-2,134-136 \\
7 \mathrm{H}-3,134-136 \\
7 \mathrm{H}-4,134-136 \\
7 \mathrm{H}-5,134-136 \\
7 \mathrm{H}-6,134-136 \\
7 \mathrm{H}, \mathrm{CC} \\
8 \mathrm{H}-1,97-99 \\
8 \mathrm{H}-2,97-99 \\
8 \mathrm{H}-3,97-99 \\
8 \mathrm{H}-4,97-99 \\
8 \mathrm{H}-5,97-99 \\
8 \mathrm{H}, \mathrm{CC} \\
9 \mathrm{H}-1,125-127 \\
9 \mathrm{H}-2,126-128 \\
9 \mathrm{H}-3,127-129 \\
9 \mathrm{H}-4,126-128 \\
9 \mathrm{H}-5,127-128 \\
9 \mathrm{H}, \mathrm{CC} \\
10 \mathrm{H}-2,86-88 \\
10 \mathrm{H}-3,85-87 \\
10 \mathrm{H}-4,85-87 \\
10 \mathrm{H}-6,100-102 \\
10 \mathrm{H}, \mathrm{CC} \\
11 \mathrm{H}-1,134-136 \\
11 \mathrm{H}-2,134-136 \\
11 \mathrm{H}-3,91-93 \\
11 \mathrm{H}-4,134-136 \\
11 \mathrm{H}-5,109-111 \\
11 \mathrm{H}-6,69-71 \\
11 \mathrm{H}, \mathrm{CC}\end{array}$ & 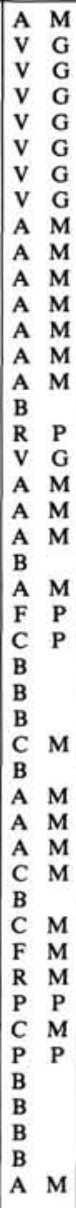 & \begin{tabular}{|l|} 
F \\
F \\
C \\
C \\
C \\
C \\
C \\
C \\
F \\
F \\
F \\
F \\
C \\
C \\
C
\end{tabular} & $\begin{array}{ll} & \mathrm{F} \\
\mathrm{C} \\
\mathrm{C} \\
\mathrm{F} \\
\mathrm{C} \\
\mathrm{F} \\
\mathrm{F} \\
\mathrm{F} \\
\mathrm{F} \\
\mathrm{R} \\
\mathrm{P} \\
\mathrm{P} \\
\mathrm{P} \\
\mathrm{F} \\
\mathrm{R} \\
\mathrm{F} \\
\mathrm{C} \\
\mathrm{R}\end{array}$ & $\begin{array}{l}\mathrm{C} \\
\mathrm{C} \\
\mathrm{C} \\
\mathrm{C} \\
\mathrm{C} \\
\mathrm{C} \\
\mathrm{C} \\
\mathrm{C} \\
\mathrm{R} \\
\mathrm{R} \\
\mathrm{F} \\
\mathrm{F} \\
\mathrm{C} \\
\mathrm{C} \\
\mathrm{C}\end{array}$ & \begin{tabular}{l|l}
$C$ & $A$ \\
$C$ & \\
$C$ & \\
$C$ & $A$ \\
$C$ & \\
$C$ & \\
$C$ & \\
$C$ & \\
$R$ & \\
$R$ & $C$ \\
$F$ & $C$ \\
$F$ & $C$ \\
$F$ & $C$ \\
$C$ & $A$ \\
$C$ & $A$ \\
$C$ & $C$
\end{tabular} & 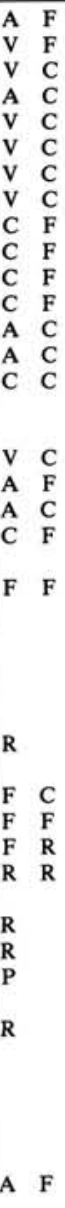 & & $\begin{array}{ll} & \mathrm{R} \\
\mathrm{F} & \mathrm{F} \\
\mathrm{R} & \mathrm{F} \\
\mathrm{R} & \mathrm{F} \\
\mathrm{R} & \mathrm{C} \\
\mathrm{R} & \mathrm{C} \\
\mathrm{R} & \mathrm{C} \\
\mathrm{R} & \mathrm{F} \\
\mathrm{P} & \mathrm{C} \\
& \mathrm{R} \\
& \mathrm{F} \\
& \mathrm{R} \\
& \mathrm{F} \\
\mathrm{P} & \mathrm{C} \\
\mathrm{R} & \mathrm{C} \\
& \\
& \\
\mathrm{P} & \mathrm{F} \\
\mathrm{R} & \mathrm{F} \\
\mathrm{R} & \mathrm{C} \\
\mathrm{P} & \mathrm{C} \\
& \\
\mathrm{C} & \mathrm{C} \\
& \mathrm{R} \\
& \mathrm{F}\end{array}$ & $\begin{array}{l}\text { A } \\
\text { A } \\
\text { A } \\
\text { A } \\
\text { A } \\
\text { A } \\
\text { C } \\
\text { A } \\
\text { C } \\
\text { C } \\
\text { C } \\
\text { C } \\
\text { C } \\
\text { C } \\
\text { C } \\
\text { R } \\
\text { A } \\
\text { A } \\
\text { C } \\
\text { A } \\
\text { A } \\
\text { F } \\
\text { F }\end{array}$ & $\begin{array}{l}\mathbf{R} \\
\mathbf{P}\end{array}$ & $\begin{array}{ll}\mathrm{P} & \\
\mathrm{F} & \mathrm{R} \\
\mathrm{F} & \mathrm{P} \\
\mathrm{F} & \mathrm{P} \\
\mathrm{F} & \mathrm{P} \\
\mathrm{R} & \mathrm{P} \\
\mathrm{F} & \mathrm{P} \\
\mathrm{F} & \\
\mathrm{F} & \\
\mathrm{P} & \\
\mathrm{P} & \\
\mathrm{R} & \\
\mathrm{R} & \\
\mathrm{R} & \end{array}$ & \begin{tabular}{|cc} 
& $\mathrm{P}$ \\
& $\mathrm{R}$ \\
& $\mathrm{R}$ \\
& $\mathrm{R}$ \\
& $\mathrm{F}$ \\
& $\mathrm{R}$ \\
$\mathrm{P}$ & $\mathrm{R}$ \\
$\mathrm{P}$ & $\mathrm{R}$ \\
& $\mathrm{R}$
\end{tabular} & $\begin{array}{l}\mathrm{P} \\
\mathrm{R} \\
\mathrm{R} \\
\mathrm{R} \\
\mathrm{F} \\
\mathrm{R} \\
\mathrm{R} \\
\mathrm{R} \\
\mathrm{R} \\
\mathrm{R}\end{array}$ \\
\hline
\end{tabular}

Abundance is characterized by $\mathrm{V}=$ very abundant, $\mathrm{A}=$ abundant, $\mathrm{C}=$ common, $\mathrm{F}=\mathrm{few}, \mathrm{R}=$ rare, $\mathrm{P}=$ present; preservation by $\mathrm{G}=$ good, $\mathrm{M}=$ moderate, $\mathrm{P}=$ poor, and $\mathrm{B}=$ barren. 
part, the upper part of the subzone is characterized by good preservation.

Both samples adjacent to the Pseudoemiliania lacunosa/Gephyrocapsa oceanica zonal boundary (105-646A-4H-6, 96-98 cm, and $105-646 \mathrm{~A}-4 \mathrm{H}-5,96-98 \mathrm{~cm}$ ) exhibit a marked reduction in general abundance of the nannofossil population. Preservation is also correspondingly poorer. Numerous reworked Cretaceous forms were observed in these two samples, including Watznaueria sp., Eiffellithus trabeculatus, Micula decussata, Nephrolithus frequens, and Prediscosphaera cretacea.

Sediments from Sample 105-646A-4H-5, 96-98 cm, through Sample 105-646A-2H-6, 104-106 cm, have been placed in the Gephyrocaspa oceanica Zone (NN20). Emiliania huxleyi has its first occurrence in Sample 105-646A-2H-5, 102-104 cm, and sediment from this point to the top of the hole is placed in the $E$. huxleyi Zone (NN21). Specimens of $E$. huxleyi become increasingly more abundant in younger sediments and are the dominant fossil in all but one sample examined. Preservation is moderate to good in most samples, and fossils are abundant to very abundant. One sample, 105-646A-2H-6, 104-106 cm, contains rare nannofossils having poor preservation. Section 105$646 \mathrm{~A}-3 \mathrm{H}, \mathrm{CC}$ is the only barren interval examined in the upper two nannofossil zones.

\section{Hole $646 B$}

The lithology of Hole 646B is composed predominantly of silty clays and clayey silts. Nannofossil abundance varies considerably throughout. Samples 105-646B-22X-7, 14-16 cm, through 105-646B-21X-1, 64-66 cm are barren, except for a single occurrence of Reticulofenestra pseudoumbilica in Sample 105-646B$22 \mathrm{X}-3,12-14 \mathrm{~cm}$. These samples fall within lithologic Subunit IB, which consists predominantly of poorly sorted muddy sands and silty muds (see Site Report, Srivastava, Arthur, et al., 1987). An alternation of nannofossil-rich samples with nannofossilpoor or barren samples occurs from Sections 105-646B-20X, CC through 105-646B-7H, CC. Sections 105-646B-80X, CC through 105-646B-22X, CC are generally nannofossil-rich (Table 2).

Overall diversity is low, and nannofossil assemblages are dominated by Coccolithus pelagicus, Reticulofenestra pseudoumbilica, Reticulofenestra spp. (small) and later, Gephyrocapsa spp. (small). Discoasters are common as a group; however, species that define the zones are generally rare and have sporadic occurrences. Amaurolithus spp. and Ceratolithus spp. are rare and were used as groups to define certain zonal boundaries. Older reworked specimens also are present within the section and include Chiasmolithus spp., Coccolithus miopelagicus, and single occurrences of Zygrhablithus bijugatus, Eiffellithus eximius, and Watznaueria sp.

The oldest sediment in this hole can be placed in the upper Miocene Discoaster calcaris Zone (NN10), and all samples from 105-646B-80X, CC through 105-646B-75X-2, 41-43 cm are assigned to this zone. This zonation is based on the presence of Discoaster berggrenii and Discoaster bergenii $\mathrm{n}$. $\mathrm{sp}$. below the lowest occurrence of $D$. quinqueramus. The presence of these two species below the lowest occurrence of $D$. quinqueramus also was recorded by Bergen (1984). A single specimen of $D$. quinqueramus observed in Section 105-646B-76X, CC, indicates that Zone NN11 may extend as low as this sample. However, this occurrence is attributed to downhole contamination.

The lowest occurrence of Discoaster quinqueramus was observed in Sample 105-646B-75X-1, 108-110 cm. Sediment from this sample through Section 105-646B-53X, CC is placed in the Discoaster quinqueramus Zone (NN11). The top of Zone NN11, which is based upon the highest occurrence of $D$. quinqueramus, is not clearly defined. Discoaster quinqueramus is rare and sporadic in the upper part of this zone. The highest ob- served occurrence of $D$. quinqueramus was found in Sample $105-646 \mathrm{~B}-43 \mathrm{X}-3,93-95 \mathrm{~cm}$. This is above the lowest occurrence of ceratoliths and suggests reworking of sediment. The highest occurrence of D. quinqueramus (Section 105-646B-53X, CC) below the lowest ceratolith thus was used as the top of Zone NN11. Two questionable specimens of Discoaster bergenii $\mathrm{n}$. sp. were observed in this zone (Sections 105-646B-71, CC and 105-646B-62, CC). These are assumed to be reworked because we did not find $D$. bergenii $\mathrm{n}$. sp. occurring elsewhere with $D$. quinqueramus (Bergen, 1984); it is apparently restricted to the NN10 subzone.

Zone NN11 tentatively has been subdivided into two subzones (NN11a and NN11b), based on the presence of Amaurolithus primus. Specimens of Amaurolithus primus were observed in Sections 105-646B-60X, CC, through 105-646B-53X, CC and indicate the presence of Subzone NN11b. The lowest occurrence of Discoaster surculus also was observed in Subzone NN11b (Section 105-646B-55X, CC). Sediment below Section 105-646B$60 \mathrm{X}, \mathrm{CC}$ to the bottom of Zone NN11 represents Subzone NN11a.

Sections 105-646B-52X, CC through 105-646B-46X, CC have been placed within the Amaurolithus tricorniculatus Zone (NN12). However, zonal assignment is tentative because of the sparseness of marker species in the overlying and underlying zones. A single specimen of Ceratolithus acutus is present in Section 105-646B-49X, CC, which places this sample through Section 105-646B-46X, CC in the upper part of the zone. This interval thus correlates with the Ceratolithus acutus Zone (CN10b) of Okada and Bukry (1980).

The lowest occurrence of Ceratolithus rugosus is present in Sample 105-646B-46X-2, 25-27 cm. Sediment from this sample through Sample 105-646B-41X-4, 43-45 cm, has been assigned to Zones NN13 and NN14. These two zones could not be delineated in this section because Discoaster asymmetricus, whose lowest occurrence delineates the boundary, is not well represented. In addition, Amaurolithus tricorniculatus could not be used to separate Zones NN14 and NN15 because it is not present in the section. The lowest occurrence of Pseudoemiliania lacunosa (Sample 105-646B-41X-3, 43-45 cm) is used here to approximate the NN14/15 boundary (Knüttel, 1986). The lowest occurrence of Pseudoemiliania lacunosa located near the highest occurrence of Amaurolithus tricorniculatus was reported similarly at DSDP Site 548 in the North Atlantic (Müller, 1985).

The highest common occurrence of Reticulofenestra pseudoumbilica is used here to define the top of Zone NN15 (Takayama and Sato, 1987). This datum was found in Sample 105646B-37X-2, 103-105 cm, which places sediment from Samples 105-646B-41X-3, 43-45 cm, through 105-646B-37X-2, 103-105 $\mathrm{cm}$, in Zone NN15. Specimens of $R$. pseudoumbilica are rare but persistent through Sample 105-646B-31X-6, 61-63 cm; these specimens may be reworked. The highest occurrence of Sphenolithus spp. and the lowest occurrence of Discoaster tamalis also were observed just above the highest common occurrence of $R$. pseudoumbilica.

Sediment from Samples 105-646B-37X-1, 103-105 cm, through $105-646 \mathrm{~b}-23 \mathrm{X}-1,62-64 \mathrm{~cm}$, has been placed in the Discoaster surculus Zone (NN16). The highest occurrences of Discoaster surculus (Sample 105-646B-23X-1, 62-64 cm), D. pentaradiatus (Sample 105-646B-23X-2, 62-64 cm), and D. tamalis (Sample 105-646B-23X-4, 62-64 cm) are present in this zone.

Boundaries between Zones NN16, NN17, and NN18 are difficult to delineate because 15 of the 23 samples examined between Samples 105-646B-23X-1, 62-64 cm, and 105-646B-18X$2,118-120 \mathrm{~cm}$, are barren of calcareous nannofossils. The entire interval from Sample 105-646B-22X-7, 14-16 cm, through Sample $105-646 \mathrm{~B}-21 \mathrm{X}-1,64-66 \mathrm{~cm}$, is essentially barren and cannot be assigned an exact zonal age. Zone NN17 could not be identi- 


\begin{tabular}{|c|c|c|c|c|c|c|c|c|c|c|c|c|c|c|c|c|c|c|c|c|c|c|}
\hline Age & $\begin{array}{c}\text { Zone } \\
\text { (After Martini } \\
\text { and Muller, } \\
\text { 1986) }\end{array}$ & $\begin{array}{l}\text { Core-section, } \\
\text { sample interval } \\
(\mathrm{cm})\end{array}$ & 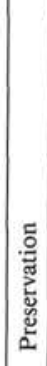 & 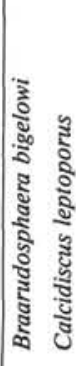 & 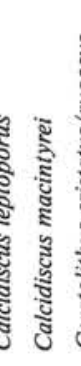 & 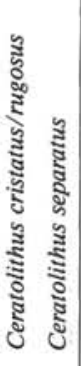 & 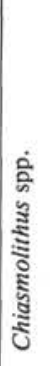 & 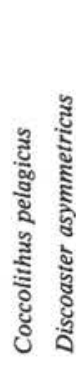 & 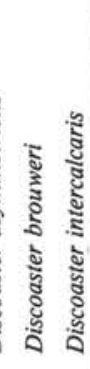 & 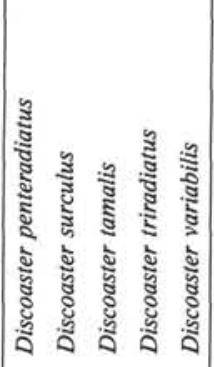 & 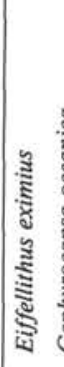 & 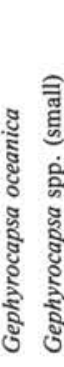 & 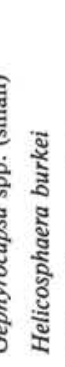 & 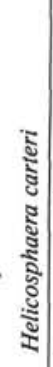 & 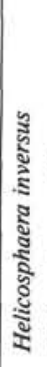 & 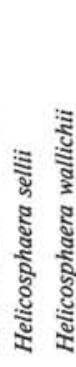 & 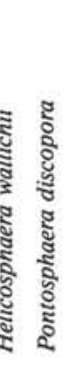 & 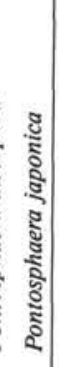 & 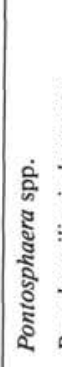 & 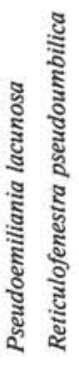 & 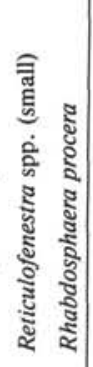 & 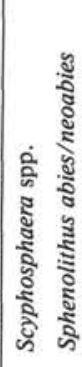 \\
\hline \multirow[t]{3}{*}{ Pleistocene } & NN19b & $\begin{array}{c}105-646 \mathrm{~B}-7 \mathrm{H}, \mathrm{CC} \\
9 \mathrm{H}, \mathrm{CC} \\
10 \mathrm{H}, \mathrm{CC} \\
11 \mathrm{H}, \mathrm{CC} \\
12 \mathrm{H}-1,92-94 \\
12 \mathrm{H}-2,92-94 \\
12 \mathrm{H}-4,92-94 \\
12 \mathrm{H}-5,92-94 \\
12 \mathrm{H}, \mathrm{CC} \\
13 \mathrm{H}-1,34-36 \\
13 \mathrm{H}-2,34-36 \\
13 \mathrm{H}-3,34-36 \\
13 \mathrm{H}-4,34-36 \\
13 \mathrm{H}-5,34-36 \\
13 \mathrm{H}-6,34-36 \\
13 \mathrm{H}, \mathrm{CC} \\
14 \mathrm{H}-1,56-58 \\
14 \mathrm{H}-2,56-58 \\
14 \mathrm{H}-3,56-58 \\
14 \mathrm{H}-4,56-58 \\
14 \mathrm{H}-5,56-58 \\
14 \mathrm{H}-6,56-58 \\
14 \mathrm{H}, \mathrm{CC}\end{array}$ & $\begin{array}{l}\mathrm{M} \\
\mathrm{M} \\
\mathrm{M} \\
\mathrm{M} \\
\mathrm{M} \\
\mathrm{M} \\
\mathrm{M} \\
\mathrm{G} \\
\mathrm{M}\end{array}$ & $\begin{array}{l}\mathrm{P} \\
\mathrm{P} \\
\mathrm{F} \\
\\
\mathrm{P} \\
\mathrm{C} \\
\mathrm{P} \\
\mathrm{R}\end{array}$ & 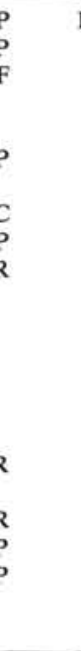 & & & $\begin{array}{l}\text { R } \\
\text { F } \\
\\
\text { A } \\
\text { P } \\
\text { C }\end{array}$ & & & & $\begin{array}{cc} & \mathrm{F} \\
& \mathrm{R} \\
\mathrm{C} \\
\mathrm{R} \\
\mathrm{R} \\
\mathrm{A} & \mathrm{A} \\
\mathrm{C} & \mathrm{A} \\
& \mathrm{F} \\
& \mathrm{A} \\
\mathrm{R} \\
\\
\end{array}$ & $\begin{array}{l}\mathrm{R} \\
\mathrm{P}\end{array}$ & $\mathbf{P}$ & $\mathrm{R}$ & $\begin{array}{ll}\text { F } & P \\
\text { P } & \end{array}$ & $\begin{array}{l}\mathrm{F} \\
\mathrm{P}\end{array}$ & $\mathrm{F}$ & F & $\begin{array}{ll}R & \\
P & \\
F & \\
& \\
P & R \\
C & \\
\text { F } & \end{array}$ & $\begin{array}{l}\mathrm{C} \\
\mathrm{C} \\
\mathrm{R} \\
\mathrm{A} \\
\mathrm{F} \\
\mathrm{C} \\
\mathrm{C} \\
\mathrm{C} \\
\mathrm{C}\end{array}$ & \\
\hline & NN19a & $\begin{array}{l}16 \mathrm{X}, \mathrm{CC} \\
18 \mathrm{X}-1,118-120 \\
18 \mathrm{X}-2,118-120\end{array}$ & \begin{tabular}{|l|}
$\mathrm{M}$ \\
$\mathrm{P}$ \\
$\mathrm{M}$
\end{tabular} & $\begin{array}{l}\text { C } \\
\text { P } \\
\text { F }\end{array}$ & $\begin{array}{ll}C & R \\
F & P\end{array}$ & & & $\begin{array}{l}\text { C } \\
\text { C } \\
\text { A }\end{array}$ & & & & $\begin{array}{ll}P & \mathrm{~A} \\
\mathrm{~F} \\
\mathrm{C}\end{array}$ & 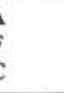 & & & F & & $P$ & $\begin{array}{ll}\mathrm{P} & 1 \\
\mathrm{P} & \\
\mathrm{P} & \end{array}$ & $\begin{array}{l}P \\
F\end{array}$ & $\begin{array}{l}\text { A } \\
\text { F } \\
\text { C }\end{array}$ & \\
\hline & NN17/NN18 & $\begin{array}{l}18 X-3,40-42 \\
18 X, C C \\
19 X, C C \\
20 X-1,81-83 \\
20 X-2,81-83 \\
20 X-3,85-87 \\
20 X-4,85-87 \\
20 X-5,85-87 \\
20 X-6,85-87 \\
20 X, C C \\
21 X-1,64-66 \\
21 X-2,64-66 \\
21 X-3,64-66 \\
21 X-4,64-66 \\
21 X-5,64-66 \\
21 X, C C \\
22 X-1,13-15 \\
22 X-2,13-15 \\
22 X-3,12-14 \\
22 X-4,14-16\end{array}$ & $\begin{array}{l}\mathrm{M} \\
\mathrm{M} \\
\mathrm{G} \\
\mathrm{P} \\
\mathrm{P}\end{array}$ & $\begin{array}{l}\text { F } \\
\text { F } \\
\text { F }\end{array}$ & $\begin{array}{l}P \\
P \\
P\end{array}$ & & & $\begin{array}{l}\text { A } \\
\text { C } \\
\text { C } \\
\\
\text { P } \\
\text { R }\end{array}$ & $\begin{array}{l}\mathrm{P} \\
\mathrm{P}\end{array}$ & & & $\begin{array}{ll}\mathrm{F} & \mathrm{A} \\
& \mathrm{C} \\
\mathrm{R} & \mathrm{C}\end{array}$ & A & $\mathbf{R}$ & $\mathrm{R}$ & F & $\mathbf{P}$ & $\mathrm{P}$ & & $\begin{array}{l}\text { F } \\
\text { R } \\
\text { F }\end{array}$ & $\begin{array}{l}\mathrm{A} \\
\mathrm{C} \\
\mathrm{A} \\
\mathrm{R} \\
\mathrm{R}\end{array}$ & \\
\hline
\end{tabular}


Table 2 (continued).

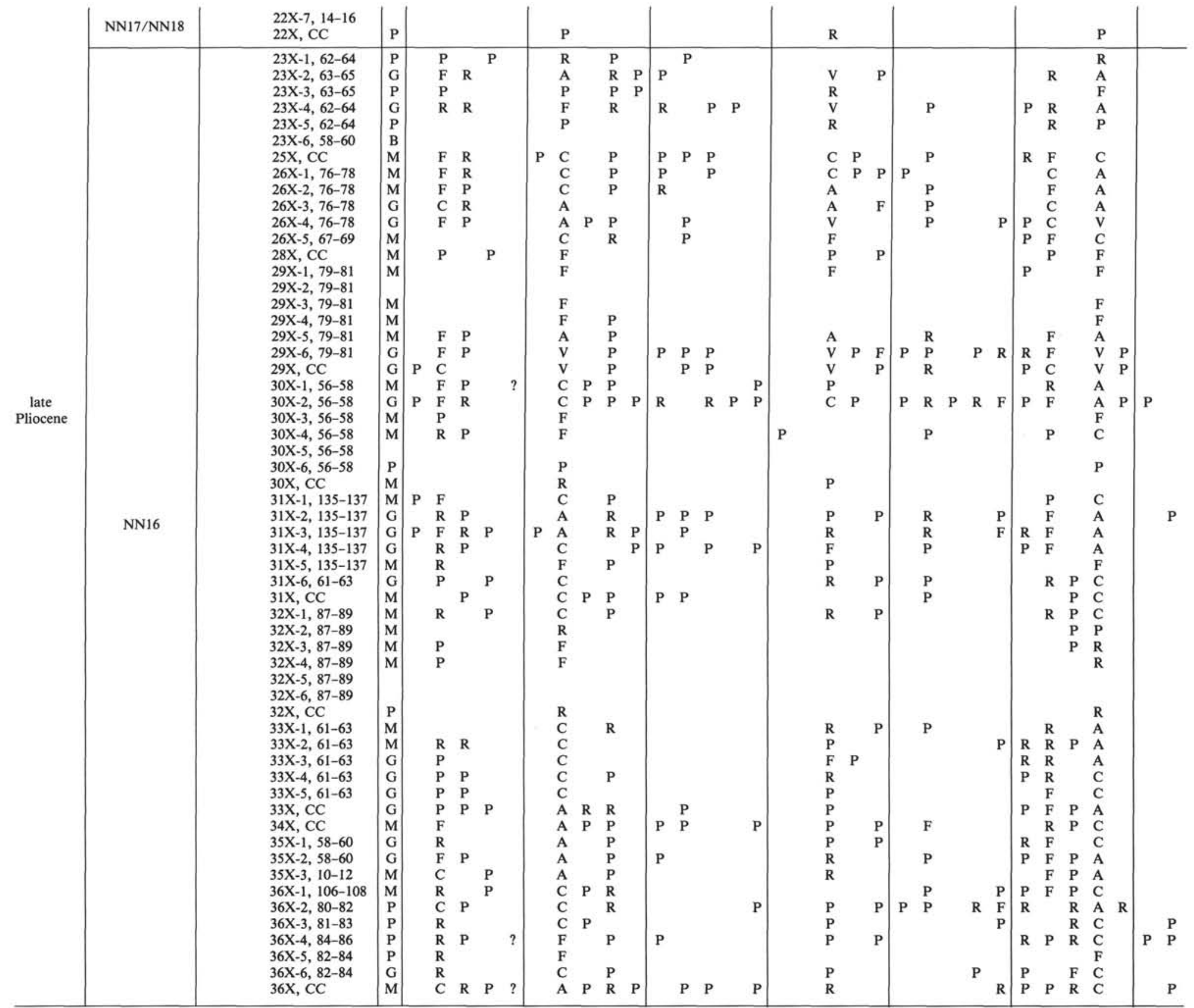




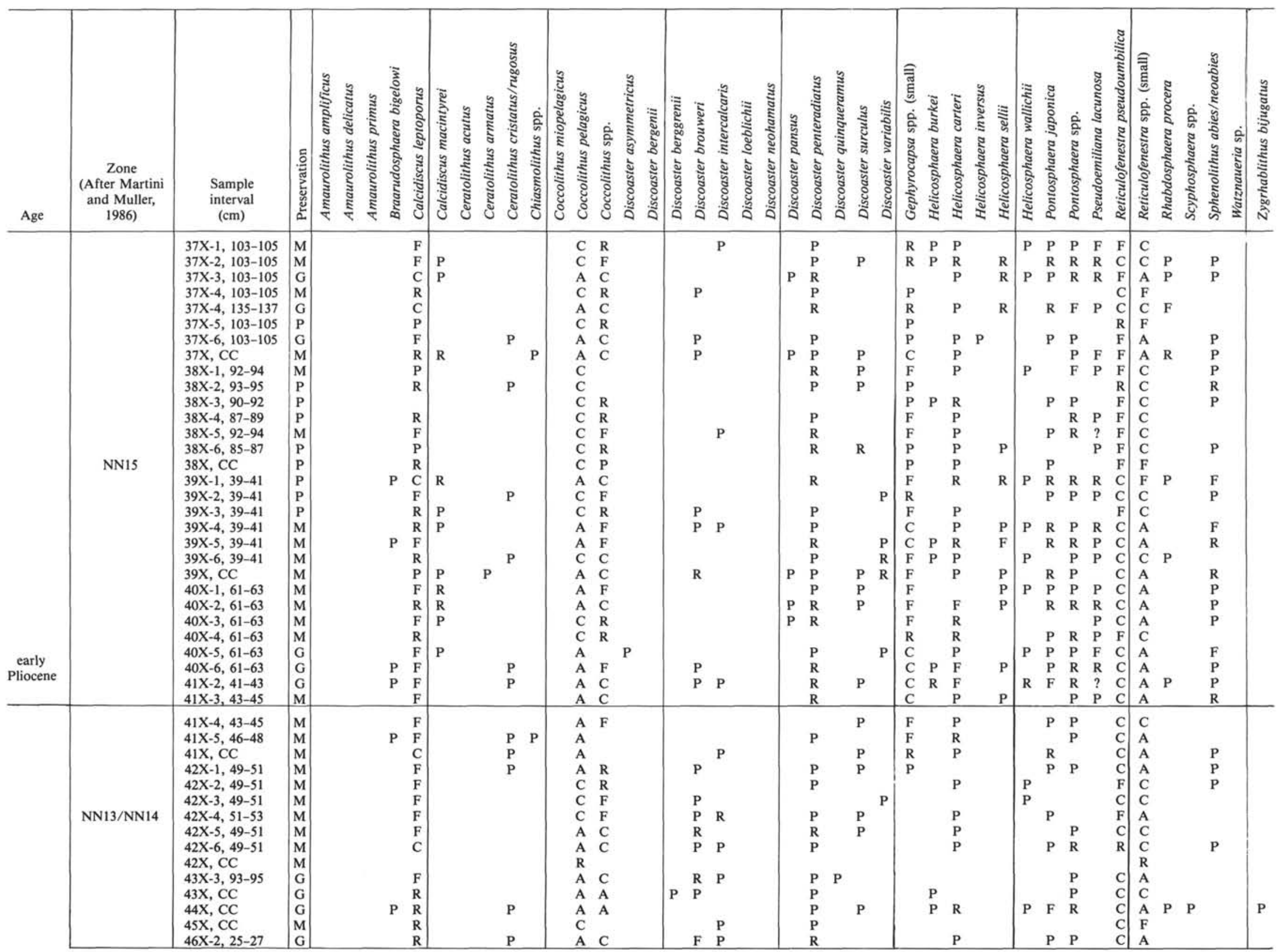


Table 2 (continued).

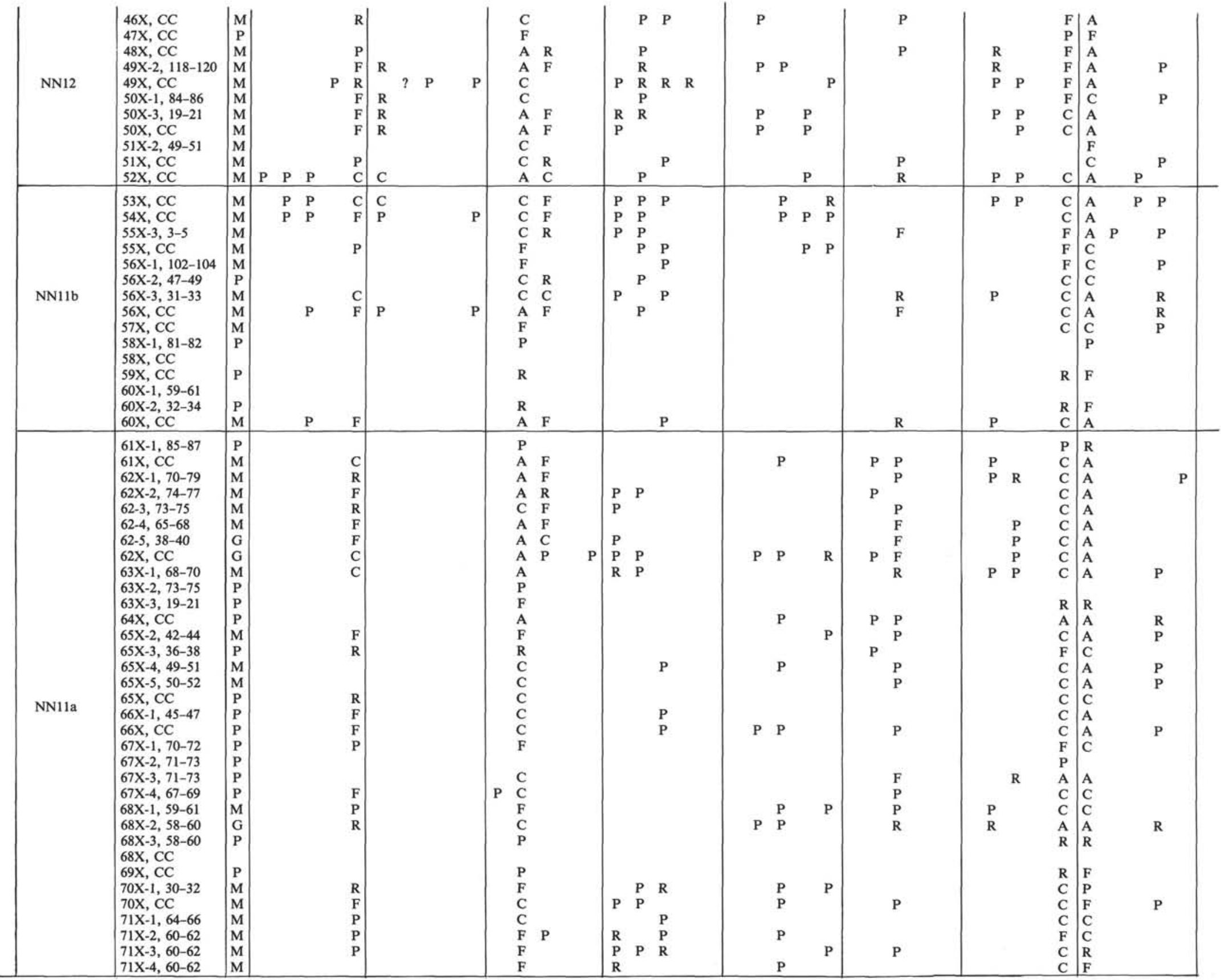


Table 2 (continued).

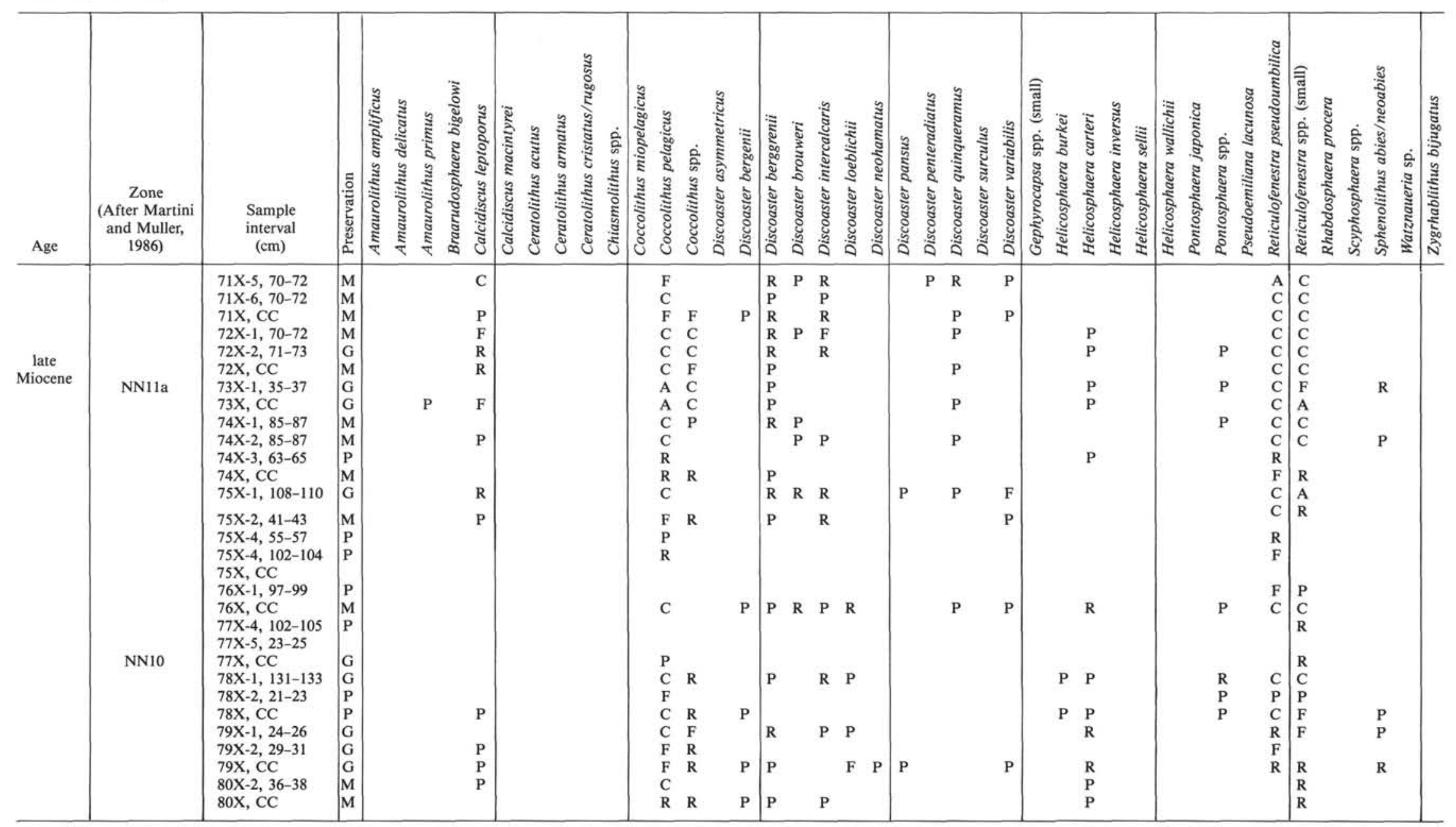


fied in this hole because the highest occurrence of Discoaster pentaradiatus was observed below the highest occurrence of $D$. surculus in Zone NN16. Discoaster brouweri, the only discoaster present in Samples 105-646B-20X-3, 85-87 cm, and 105646B-18X-3, 40-42 cm, places sediment within this interval in the $D$. brouweri Zone (NN18).

Zone NN19 is represented by Samples 105-646B-18X-2, 118$120 \mathrm{~cm}$, through $105-646 \mathrm{~B}-7 \mathrm{H}, \mathrm{CC}$. The highest occurrence of Calcidiscus macintyrei (observed in Section 105-646B-16X, CC) was used to subdivide this zone. Sediment in samples from the bottom of the zone up to Section 105-646B-16X, CC is placed within Subzone NN19a, and sediment above this point is placed within Subzone NN19b. The NN19a/NN19b subzonal boundary is used here to approximate the Pliocene/Pleistocene boundary (Backman et al., 1983). In Hole 646B, the highest occurrence of Helicosphaera sellii also was observed in Subzone NN19b in Sample 105-646B-12H-5, 92-94 cm.

\section{Site 647}

Site 647 is located on the south flank of the Gloria Drift at $53^{\circ} 19.9^{\prime} \mathrm{N}$ and $45^{\circ} 15.7^{\prime} \mathrm{W}$ (Fig. 1). Holes 647A and 647B were drilled at this site at a water depth of $3869 \mathrm{~m}$. Of the two holes cored, only the Neogene from Hole 647A was examined in detail (Table 3). Fourteen samples were examined from Hole 647B to cover the coring gap (Core 105-647A-3R) in Hole 647A. Hole $647 \mathrm{~A}$ was cored by rotary drilling and was completed to a depth of 736 mbsf. The Neogene section is contained in the upper 13 cores of this hole.

The Neogene section recovered from Hole $647 \mathrm{~A}$ is contained within lithologic Units I and II (see Site 647 chapter, Srivastava, Arthur, et al., 1987). Unit I is characterized by silty clay and clayey sediments having variable amounts of biogenic carbonate. Nannofossils are present only in lithologic Subunit IIA (between 116 and 119 mbsf, Core 105-647A-13R), which is composed of a yellowish-brown nannofossil clay.

The oldest Neogene calcareous nannofossil assemblage in Hole 647A is found in the upper two sections of Core 105-647A13R. These sediments are placed in the upper Miocene Discoaster calcaris/Discoaster quinqueramus zones (NN10/11). As a group discoasters are common; however, zonal markers are rare. Rare specimens of Discoaster bollii were observed in Sample 105-647A-13R-2, 53-55 cm; because of these occurrences, we tentatively place this sample in Zone NN10. Species questionably identified as Discoaster quinqueramus also are present. Sample 105-647A-13R-1, 53-55 cm, contains Discoaster quinqueramus, Discoaster berggrenii, and Discoaster loeblichii and is placed in Subzone NN11a. Samples examined in Core 105$647 \mathrm{~A}-13 \mathrm{R}$ below these two samples are barren of calcareous nannofossils.

Samples examined directly above Core 105-647A-13R (Section 105-647A-12R, CC through Sample 105-647A-12R-3, 39-41 $\mathrm{cm}$ ) are assigned to the upper Pliocene Discoaster surculus Zone (NN16). Frequent Pseudoemiliania lacunosa and Discoaster tamalis were first observed in this zone.

The assemblage characteristic of the Discoaster pentaradiatus Zone (NN17) was recognized only in Sample 105-647A-12R$1,93-95 \mathrm{~cm}$. Both samples examined above and below this sample (Samples 105-647A-12R-2, 93-95 cm, and 105-647A-11R, CC) are barren of calcareous nannofossils. Discoasters are few, and Discoaster pentaradiatus was observed only rarely.

Sediment in Samples 105-647A-11R-4, 35-37 cm, through 105-647A-10R-3, 45-47 cm, are placed in the Discoaster brouweri Zone (NN18). Discoasters are rare within the zone. Specimens of Discoaster triradiatus are present and were observed only in this zone.

Samples from 105-647A-10R-2, 45-47 cm, through 105-647A$4 \mathrm{R}-1,138-140 \mathrm{~cm}$ and from $105-647 \mathrm{~B}-4 \mathrm{H}-2,80-85 \mathrm{~cm}$, through
105-647B-3H-3, 120-125 cm, are placed in the upper Pleistocene Pseudoemiliania lacunosa Zone (NN19). In Hole 647A, this zone was subdivided further into Subzones NN19a and NN19b, based on the presence of Calcidiscus macintyrei. The highest occurrence of Calcidiscus macintyrei was observed in Sample 105-647A-9R-1, 49-51 cm, which places sediment from this sample to the bottom of the hole in the NN19a subzone. Sediment from Section 105-647A-8R, CC through Sample 105$647 \mathrm{~A}-4 \mathrm{R}-1,138-140 \mathrm{~cm}$, thus has been placed in Subzone NN19b.

The Pseudoemiliania lacunosa Zone and two overlying zones are characterized primarily by good preservation. Nannofossil diversity is similar to that at Site 646. Preservation and abundance of nannofossils within these zones do not vary as much as at Site 646, and barren intervals are absent.

Sediment from Section 105-647A-2R, CC through Sample 105-647A-1R-7, 14-16 cm, and Samples 105-647B-3H-2, 80-85 $\mathrm{cm}$, through $105-647 \mathrm{~B}-2 \mathrm{H}-4,80-85 \mathrm{~cm}$, have been placed in the Gephyrocapsa oceanica Zone (NN20). Emiliania huxleyi has its lowest occurrence in Sample 105-647A-1R-6, 130-132 cm, which places sediment from this point to the top of Hole 647A in the E. huxleyi Zone (NN21).

\section{COCCOLITHUS PELAGICUS ABUNDANCE PEAKS AND CLIMATIC/OCEANIC TRENDS}

As mentioned previously, particular attention has been given to the changes in relative species abundances of Coccolithus pelagicus, Emiliania huxleyi, Gephyrocapsa spp., and Reticulofenestra spp. (small) for a possible interpretation of the oceanic circulation history of the area and the connection with glacial/ interglacial episodes. We noted extreme variations in the population of Coccolithus pelagicus at Sites 646 and 647. In samples from the upper section of Hole 646A (above Section 105-646A$3 \mathrm{H}, \mathrm{CC}$ ) where $C$. pelagicus is abundant, specimens of $E$. huxleyi, Gephyrocapsa spp., and Reticulofenestra spp. (small) are fewer. The opposite is true for samples where $E$. huxleyi, Gephyrocapsa spp., and Reticulofenestra spp. (small) dominate the assemblage. In these samples, $C$. pelagicus is virtually absent. Samples examined below Section 105-646A-3H, CC, contain assemblages having higher numbers of these species interlayered with samples that are generally lower in overall numbers of nannofossils.

Variation in preservation throughout the section may explain minor changes in the nannofossil population. Dissolution of certain nannofossils may have concentrated more resistant species such as C. pelagicus (Schneidermann, 1977). However, abundance peaks were observed in sediments with good preservation. Less resistant nannofossils, such as Syrachosphaera pulchra and Pontosphaera spp. are present in samples with high and low percentages of $C$. pelagicus. Hence, we believe it unlikely that preservation alone is responsible for the great fluctuations observed in the abundances of $C$. pelagicus.

The relationship between these species and their relative abundance trends is interpreted to reflect changes in surface-water masses in response to climatic cooling and warming trends. This rationale previously was used in the Northern Hemisphere (McIntyre et al., 1972; McIntyre and Ruddiman, 1972; Ruddiman and McIntyre, 1976) and in the Southern Hemisphere (Geitzenauer, 1969, 1972) and is thought to result from cool and warm episodes associated with variations in northern and southern hemispheric glaciation. Four characteristic assemblages were designated in the North Atlantic by McIntyre et al. (1972): a cold subpolar assemblage dominated by Emiliania huxleyi and Gephyrocapsa caribbeanica; a warm subpolar assemblage with the addition of $C$. pelagicus; a transitional assemblage with $C$. pelagicus and cool subtropical species; and a subtropical assemblage with a diverse flora. Geitzenauer $(1969,1972)$ also sug- 
gested that assemblages with higher frequencies of $C$. pelagicus and Calcidiscus leptoporus were characteristic of "cool" interglacial stages and that assemblages with higher frequencies of Gephyrocapsa spp. were from the colder glacial stages.

Several abundance peaks of Coccolithus pelagicus are present from the upper Pseudoemiliania lacunosa Zone (NN19) to the top of the hole (Figs. 3 and 4). Higher frequencies of $C$. pelagicus are present within the uppermost range of $P$. lacunosa (Samples 105-646A-5H-3, 104-106 cm; 105-646A-5H-1, 104-106 $\mathrm{cm}$; $105-646 \mathrm{Aa}-4 \mathrm{H}, \mathrm{CC}$ and $105-647 \mathrm{~B}-3 \mathrm{H}-4,80-85 \mathrm{~cm}$ ), whereas it has rarely been seen near the extinction datum of $P$. lacunosa (Samples 105-646A-4H-6, 96-96 cm; 105-646A-4H-5, 96-98 cm; and $105-647 \mathrm{~B}-3 \mathrm{R}-3,120-125 \mathrm{~cm}$ ).

In the $G$. oceanica Zone (NN20), abundance peaks were observed for $C$. pelagicus in Hole 646A. These can be seen in Samples 105-646A-4H-4, 96-98 cm, through 105-646A-4H-1, 96-98 $\mathrm{cm}$, and in Samples 105-646A-3H-3, 80-82 cm, and 105-646A$3 \mathrm{H}-1,80-82 \mathrm{~cm}$. A barren interval (Section 105-646A-3H, CC) and an almost barren interval (Sample 105-646A-2H-6, 104-106 $\mathrm{cm})$ also were observed in this zone.

Abundances of $C$. pelagicus vary greatly within the Emiliania huxleyi Zone (NN21). Sample 105-646A-2H-2, 102-104 cm and Section 105-646A-1H, CC contain common to abundant $C$. pelagicus, and Sample 105-646A-1H-1, 48-50 cm contains extremely abundant $C$. pelagicus. Abundances of $C$. pelagicus are much lower in Samples 105-646A-2H-4, 102-104 cm; 105-646A$2 \mathrm{H}-1,102-104 \mathrm{~cm}$ and $105-646 \mathrm{~A}-1-2 \mathrm{H}, 48-50 \mathrm{~cm}$. In these samples, E. huxleyi and Gephyrocapsa oceanica form a major part of the assemblage.

Abundance peaks of $C$. pelagicus have been correlated with isotopic data for these sites (Aksu et al., this volume) and the glacial/interglacial isotope stages defined by Emiliani (1955), Kellogg (1975, 1976), Kellogg et al. (1978), Shackleton and Opdyke (1973), and others. A correlation exists between higher numbers of $C$. pelagicus and the interglacial isotope stages and/or glacial/interglacial isotope-stage boundaries (Figs. 3 and 4). This is most apparent in isotope stage 1 (Sample 105-646A-1H-1, 48$50 \mathrm{~cm}$ ), isotope stage 3 (Section 105-646A-1H, CC), between isotope stages 10 and 11, and in stage 11 (Samples 105-646A$4 \mathrm{H}-1,96-98 \mathrm{~cm}$, through $105-646 \mathrm{~A}-4 \mathrm{H}-4,96-98 \mathrm{~cm}$, and $105-$ 647B-3H-2, 80-85 cm), between isotope stages 12 and 13 (Section 105-646A-4H, CC and Sample 105-646A-5H-1, 104-106 cm), and between isotope stages 13 and 14 (Sample 105-646A-5H-3, $104-106 \mathrm{~cm})$. Lower numbers of $C$. pelagicus were observed in glacial isotope stage 2 (Sample $105-646 \mathrm{~A}-1 \mathrm{H}-2,48-50 \mathrm{~cm}$ ), isotope stage 6 (Samples 105-646A-2H-3, 102-104 cm, and 105$646 \mathrm{~A}-2 \mathrm{H}-4,102-104 \mathrm{~cm}$ ), isotope stage 10 (Section 105-646A$3 \mathrm{H}, \mathrm{CC}$ ), isotope stage 12 (Samples 105-646A-4H-5, 96-98 cm; $105-646 \mathrm{~A}-4 \mathrm{H}-6,96-98 \mathrm{~cm}$, and 105-647B-3H-3, 120-125 cm), and isotope stage 14 (Samples 105-646A-5H-4, 104-106 cm, through 105-646A-5H-5, 104-106 cm). Anomalously high numbers of $C$. pelagicus in glacial stages were observed in isotope stage 8 (Sample 105-646A-3H-3, 80-82 cm).

Changes in surface-water masses in response to climatic shifts can be interpreted from these observations. In the upper Pseudoemiliania lacunosa Zone (NN19), two transitional trends are recorded by the abundance peaks of $C$. pelagicus. The first occurs at the end of isotope stage 14 and the second at the boundary between isotope stages 13 and 12 . These abundance peaks may represent a cool transitional period between isotope stages 14 and 13 and isotope stages 13 and 12 , where conditions for $C$. pelagicus were at a maximum. This rationale follows that of Geitzenauer (1972) where excess climatic warming or cooling caused the ecological exclusion of $C$. pelagicus from the area.

The highest occurrence of $P$. lacunosa is recorded in isotope stage 12 . The end of this stage is marked by rare $C$. pelagicus and shows advanced dissolution with lower overall numbers of calcareous nannofossils. This situation is similar to that in Core
V28-56 from the Norwegian Sea $\left(68^{\circ} 02^{\prime} \mathrm{N}, 06^{\circ} 07^{\prime} \mathrm{W}\right)$ in which low total calcium carbonate was recorded (Kellogg, 1977; Kellogg et al., 1978).

A long cool interglacial period may be indicated in isotope stage 11 by consistently high occurrences of $C$. pelagicus along with very abundant Gephyrocapsa spp. and Reticulofenestra spp. (small) and an increased number of other cool subtropical species. An increase in calcium carbonate content in sediments representing oxygen isotope stage 11 was also recorded in Core V28-56 (Kellogg et al., 1978). Isotopic data for this interval at Site 646 (Aksu et al., this volume), however, suggest somewhat warmer conditions. Glacial isotope stage 10 is marked by a carbonate minimum at Site 646 in which calcareous nannofossils are absent.

Within the upper Gephyrocapsa oceanica Zone (NN20), no C. pelagicus abundance peaks are recorded in isotope stages 7 and 9 or at the $10 / 9$ stage boundary. These abundance peaks may occur in the sediments but possibly were missed by the sampling interval. Within the top $1.5 \mathrm{~m}$ of Hole $646 \mathrm{~A}$, the abundance of $C$. pelagicus changes from extremely abundant to rare. Such rapid changes could easily be missed by the sampling interval if they did occur. A more detailed analysis will be required to verify the presence or absence of these peaks. It is also possible that minor hiatuses erased some of the $C$. pelagicus peaks or that some sections were not recovered during coring operations.

Glacial isotope stage 8 is marked by more abundant $C$. pelagicus slightly above the $9 / 8$ stage boundary and by common $C$. pelagicus at the $8 / 7$ boundary. Isotopic data (Aksu et al., this volume) in this stage indicate a general cold trend with several periods of somewhat cool climatic conditions. If the isotopic data reliably reflect climatic conditions, more temperate periods may be suggested during glacial stage 8 , where conditions for $C$. pelagicus were at a maximum. A similar peak in warmer-water dinoflagellate species occurring in lower stage 8 (Aksu et al., this volume) also supports this interpretation.

Several fluctuations in the population of $C$. pelagicus are recorded within the $E$. huxleyi Zone (NN21). Cold polar assemblages that contain sparse $C$. pelagicus are bounded by cool subpolar assemblages with common to abundant $C$. pelagicus. The early part of the zone contains a less well-defined $C$. pelagicus abundance peak at the boundary between isotope stages 6 and 5 (this abundance peak may not have been observed because of the sampling interval). The upper part of the zone records two well-defined $C$. pelagicus abundance peaks, of which the latter contains an assemblage dominated by $C$. pelagicus. This assemblage most likely represents a surface-water temperature of approximately 8 to $10^{\circ} \mathrm{C}$, which is the optimum temperature for C. pelagicus (McIntyre and Bé, 1967). This last abundance peak also occurs during isotope stage 1 , which is one of the two major interglacial pulses recorded within the late Pleistocene (Kellogg, 1977).

\section{SUMMARY AND CONCLUSIONS}

Neogene calcareous nannofossils were examined from all three sites cored during ODP Leg 105. Most samples examined from the six holes at Site 645 in Baffin Bay are barren of calcareous nannofossils, and sparse nannofossils occur in others. A lower Miocene assemblage is present in the bottom part of Hole 645E.

Site 646 in the Labrador Sea contains a thick, relatively complete, high-latitude upper Miocene to Holocene section. Hole 646A contains upper Pleistocene through Holocene sediments, whereas Hole 646B yielded an upper Miocene through upper Pleistocene sequence. In comparison, Site 647 contains a condensed upper Pleistocene through Holocene sequence unconformably overlying a thin upper Miocene unit.

Upper Pleistocene fossil coccolithophorid floras show welldeveloped alternations of cold subpolar assemblages with cool transitional (subpolar/subtropical) assemblages. Within these as- 


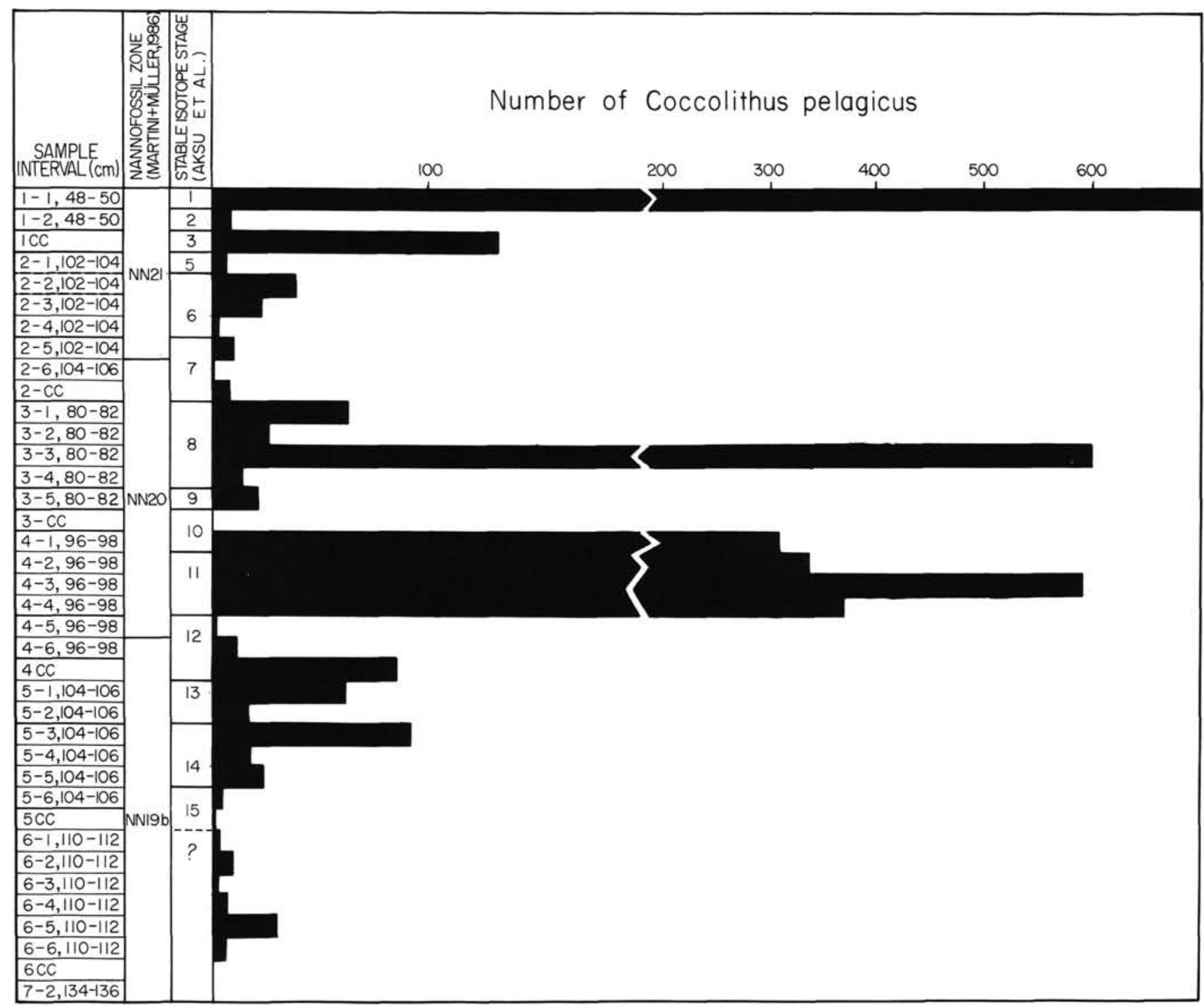

Figure 3. Correlation of nannofossil zones, stable-isotope stages (Aksu et al., this volume) and actual number of individuals of Coccolithus pelagicus observed in 100 fields of view at $1250 \times$ magnification in selected samples from Hole 646A.

semblages extreme variations in the population of Coccolithus pelagicus are recorded. An assemblage dominated by $C$. pelagicus was found in sediments deposited during the present interglacial pulse (isotope stage 1). We interpret this abundance peak as an ecological response to the introduction of cool surface waters associated with the last interglacial stage. Other abundance peaks of $C$. pelagicus have been noted in older isotope stages. These suggest past incursions of warmer surface-water masses into the study area in response to climatic warming.

The variations in abundance of Coccolithus pelagicus within the sedimentary column may be a useful tool for interpreting past climatic events if care is taken to incorporate them with other available data. However, we only recommend this method for use in the poleward part of the geographic range of Coccolithus pelagicus, where northward migrations of cool-water masses affect its relative abundance. The successful application of this method could provide a quick, reliable technique for delineating probable isotope stages, which then could be applied readily to shipboard investigations.

\section{ACKNOWLEDGMENTS}

We thank S. W. Wise, Jr., for a critical review of the manuscript. Ali Aksu provided the stable isotopic data, for which we are indebted. We thank the American taxpayer for funding this study through Grant No. 1892-BOS (awarded to S. W. Wise, Jr., and J. V. Firth), which made this report possible.

\section{REFERENCES}

Backman, J., and Shackleton, N. J., 1983. Quantitative biochronology of Pliocene and early Pleistocene calcareous nannofossils from the Atlantic, Indian, and Pacific oceans. Mar. Micropaleontol., 8:141170.

Backman, J., Shackleton, N. J., and Tauxe, L., 1983. Quantitative nannofossil correlation to open ocean deep-sea sections from Plio-Pleistocene boundary at Vrica, Italy. Nature, 304:156-158.

Bergen, J. A., 1984. Calcareous nannoplankton from Deep Sea Drilling Project Leg 78A: evidence for imbricate underthrusting at the Lesser Antillian active margin. In Biju-Duval, B. Moore, J. C., et al., Init. Repts. DSDP, 78 (Pt. 1): Washington (U.S. Govt. Printing Office), 411-445.

Berggren, W. A., Kent, D. V., and Flynn, J. J., 1985. Paleogene geochronology and chronostratigraphy. In Snelling, N. J. (Ed.), Geochronology and the Geologic Time Scale. Geol. Soc. London, Mem., 10:141-195.

Bramlette, M. N., and Wilcoxin, J. A., . Middle Tertiary calcareous nannoplankton of the Cipero Section, Trinidad, W. I. Tulane Stud. Geol. Paleontol, 5:93-131. 
Bukry, D., 1971. Discoaster evolutionary trends. Micropaleontology, $17(1): 43-52$.

Emiliani, C., 1955. Pleistocene temperatures. J. Geol., 63:538-578.

Geitzenauer, K. R., 1969. Coccoliths as late Quaternary palaeoclimatic indicators in the subantarctic Pacific Ocean. Nature, 223(5202):170172.

1972. The Pleistocene calcareous nannoplankton of the subantarctic Pacific Ocean. Deep-Sea Res., 19:45-60.

van Heck, S. E., 1979a. Bibliography and taxa of calcareous nannoplankton. Int. Nannoplank. Assoc. Newsl., 1:AB1-5, A1-12, B1-27. $1979 \mathrm{~b}$. Bibliography and taxa of calcareous nannoplankton. Int. Nannoplank. Assoc. Newsl., 1:AB VI, A13-28, B28-42. 1980a. Bibliography and taxa of calcareous nannoplankton. Int. Nannoplank. Assoc. Newsl., 2:5-34.

1980b. Bibliography and taxa of calcareous nannoplankton. Int. Nannoplank. Assoc. Newsl., 2:43-81.

1981a. Bibliography and taxa of calcareous nannoplankton. Int. Nannoplank. Assoc. Newsl., 3:4-41.

1981b. Bibliography and taxa of calcareous nannoplankton. Int. Nannoplank. Assoc. Newsl., 3:51-86.

1982a. Bibliography and taxa of calcareous nannoplankton. Int. Nannoplank. Assoc. Newsl., 4:7-50.

1982b. Bibliography and taxa of calcareous nannoplankton. Int. Nannoplank. Assoc. Newsl., 4:65-96.

1983a. Bibliography and taxa of calcareous nannoplankton. Int. Nannoplank. Assoc. Newsl., 5:4-13.

1983b. Bibliography and taxa of calcareous nannoplankton. Int. Nannoplank. Assoc. Newsl., 5:29-47.

1984. Bibliography and taxa of calcareous nannoplankton. Int. Nannoplank. Assoc. Newsl., 6:6-37.

Kellogg, T. B., 1975. Late Quaternary climatic changes in the Norwegian and Greenland seas. In Bowling, S. A., and Weller, G. (Eds.), Climate of the Arctic: Fairbanks (University of Alaska).

1976. Late Quaternary climatic changes: evidence from deepsea cores of Norwegian and Greenland seas. In Cline, R. M., and Hays, J. D. (Eds.), Investigation of Late Quaternary Paleoceanography and Paleoclimatology. Geol. Soc. Am. Mem., 145:77-110. , 1977. Paleoclimatology and paleoceanography of the Norwegian and Greenland seas: the last 450,000 years. Mar. Micropaleontol., 2:235-249.

Kellogg, T. B., Duplessy, J. C., and Shackleton, N. J., 1978. Planktonic foraminiferal and oxygen isotopic stratigraphy and paleoclimatology of Norwegian Sea deep-sea cores. Boreas, 7:61-73.

Knüttel, S., 1986. Calcareous nannofossil biostratigraphy of the central East Pacific Rise, Deep Sea Drilling Project Leg 92: evidence for downslope transport of sediments. In Leinen, M., Rea, D. K., et al., Init. Repts. DSDP, 92: Washington (U.S. Govt. Printing Office), 255-290.

Loeblich, A. R., Jr., and Tappan, H., 1966. Annotated index and bibliography of the calcareous nannoplankton. Phycologia, 5(2/3):81216.

1968. Annotated index and bibliography of the calcareous nannoplankton II. J. Paleontol., 42:584-598.

1969. Annotated index and bibliography of the calcareous nannoplankton III. J. Paleontol., 43:568-588.

,1970a. Annotated index and bibliography of the calcareous nannoplankton IV. J. Paleontol., 44:558-574.

$1970 \mathrm{~b}$. Annotated index and bibliography of the calcareous nannoplankton V. Phycologia, 9:157-174.

1971. Annotated index and bibliography of the calcareous nannoplankton VI. Phycologia, 10:315-339.

1973. Annotated index and bibliography of the calcareous nannoplankton VII. J. Paleontol., 47:715-759.

1978. The coccolithophorid genus Calcidiscus Kamptner and its synonyms. J. Paleontol., 52:1390-1392.

Martini, E., 1971. Standard Tertiary and Quaternary calcareous nannoplankton zonation. In Farinacci, A. (Ed.), Proc. Second Planktonic Conf., Rome 1970, 2:739-785.

Martini, E., and Müller, C., 1986. Current Tertiary and Quaternary calcareous nannoplankton stratigraphy and correlations. News. Strat., 16(2):99-112.

McIntyre, A., and Bé, A.W.H., 1967. Modern Coccolithophoridae of the Atlantic Ocean-I. Placoliths and Cyrtoliths. Deep-Sea Res., 14: 561-597.
McIntyre, A., and Ruddiman, F., 1972. Northeast Atlantic post-Eemian paleoceanography: a predictive analog of the future. Quat. Res., 2(3):350-354.

McIntyre, A., Ruddiman, W. F., and Jantzen, R., 1972. Southward penetrations of the North Atlantic Polar Front; faunal and floral evidence of large-scale surface-water mass movements over the last 225,000 years. Deep-Sea Res. 19:61-77.

Müller, C., 1976. Tertiary and Quaternary calcareous nannoplankton in the Norwegian-Greenland Sea, DSDP, Leg 38. In Talwani, M., Udintsev, G., et al., Init. Repts. DSDP, 38: Washington (U.S. Govt. Printing Office), 823-841.

1985. Biostratigraphic and paleoenvironmental interpretation of the Goban Spur region based on a study of calcareous nannoplankton. In de Graciansky, P. C., Poag, C. W., et al., Init. Repts. $D S D P, 80$ : Washington (U.S. Govt. Printing Office), 573-599.

Okada, H., and Bukry, D., 1980. Supplementary modification and introduction of code numbers to the low-latitude coccolith biostratigraphic zonation (Bukry, 1973; 1975). Mar. Micropaleontol., 5:321325 .

Ruddiman, W. F., and McIntyre, A., 1976. Northeast Atlantic paleoclimatic changes over the past 600,000 years. In Cline, R. M., and Hays, J. D. (Eds.), Investigation of Late Quaternary Paleoceanography and Paleoclimatology. Geol. Soc. Am. Mem., 145:111-146.

Schneidermann, N., 1977. Selective dissolution of Recent coccoliths in the Atlantic Ocean. In Ramsay, A.T.S. (Ed.), Oceanic Micropaleontology: New York (Academic Press), 1009-1053.

Shackleton, N. J., and Opdyke, N. D., 1973. Oxygen isotope and paleomagnetic stratigraphy of equatorial Pacific core V28-238: oxygen isotope temperatures and ice volumes on a $10^{5}$ year and $10^{6}$ year scale. Quat. Res., 3:39-55.

Srivastava, S. P., Arthur, M., et al., 1987. Proc. ODP, Init. Repts., 105: College Station, TX (Ocean Drilling Program).

Takayama, T., and Sato, T., 1987. Coccolith biostratigraphy of the North Atlantic Ocean, Deep Sea Drilling Project Leg 94. In Ruddiman, W. F., Kidd, R. B., Thomas, E., et al., Init. Repts. DSDP, 94 (Pt. 2): Washington (U.S. Govt. Printing Office), 651-702.

Date of initial receipt: 20 July 1987

Date of acceptance: 5 February 1988

Ms 105B-130

\section{APPENDIX A \\ Calcareous Nannofossils from Leg 105}

The calcareous nannofossil species considered in this report are listed here and arranged alphabetically by their specific epithets. Bibliographic references for those taxa not listed in the "References" section are presented by Loeblich and Tappan (1966-1978) or by van Heck (19791984).

Sphenolithus abies Deflandre, 1953

Ceratolithus acutus Gartner and Bukry, 1974

Helicosphaera ampliaperta Bramlette and Wilcoxon, 1967

Amaurolithus amplificus (Bukry and Percival) Gartner and Bukry, 1975

Umbilicosphaera angustiforamen Okada and MacIntyre, 1977

Ceratolithus armatus Müller, 1974

Discoaster asymmetricus Gartner, 1969

Discoaster bergenii $\mathrm{n}$. sp.

Discoaster berggrenii Bukry, 1971

Braarudosphaera bigelowii (Gran and Braarud) Deflandre, 1947

Discoaster braarudii Bukry, 1971

Discoaster brouweri Tan, 1927

Helicosphaera carteri (Wallich) Kamptner, 1954

Rhabdosphaera clavigera Murray and Blackman, 1898

Umbilicosphaera cricota (Gartner) Cohen and Reinhardt, 1968

Ceratolithus cristatus Kamptner, 1950

Amaurolithus delicatus Gartner and Bukry, 1975

Scapholithus fossilis Deflandre, 1954

Gephyrocapsa spp. (small) Rio, 1982

Emiliania huxleyi (Lohmann) Hay and Mohler, in Hay et al., 1976

Discoaster intercalaris Bukry, 1971

Helicosphaera inversa Gartner, 1980

Pseudoemiliania lacunosa (Kamptner) Gartner, 1969 
Calcidiscus leptoporus (Murray and Blackman) Loeblich and Tappan, 1978

Calcidiscus macintyrei (Bukry and Bramlette) Loeblich and Tappan, 1978

Umbilicosphaera mirabilis Lohmann, 1902

Sphenolithus neoabies Bukry and Bramlette, 1969

Gephyrocapsa oceanica Kamptner, 1943

Coccolithus pelagicus (Wallich) Schiller, 1930

Discoaster pentaradiatus Tan, 1927

Pontosphaera discopora Schiller, 1925

Pontosphaera japonica (Takayama) Nishida, 1971

Amaurolithus primus (Bukry and Percival) Gartner and Bukry, 1975

Rhabdosphaera procera Martini, 1969

Reticulofenestra pseudoumbilica (Gartner) Gartner, 1969

Syracosphaera pulchra Lohmann, 1902

Discoaster quinqueramus Gartner, 1969

Reticulofenestra spp. (small)

Ceratolithus rugosus Bukry and Bramlette, 1968

Helicosphaera sellii (Bukry and Bramlette) Jafar and Martini, 1975

Discoaster surculus Martini and Bramlette, 1963

Discoaster tamalis Kamptner, 1967

Amaurolithus tricorniculatus (Gartner) Gartner and Bukry, 1975

Discoaster triradiatus Tan, 1927

Discoaster variabilis Martini and Bramlette, 1963

Helicosphaera wallichii (Lohmann) Boudreaux and Hay, 1969

\section{Reworked Taxa}

Zygrhablithus bijugatus (Deflandre) Deflandre, 1959

Prediscosphaera cretacea (Arkhangelsky) Gartner (1968)

Micula decussata Vekshina, 1959

Nephrolithus frequens Gorka, 1957

Coccolithus miopelagicus Bukry, 1971

Chiasmolithus spp.

Watznaueria spp.

Eiffellithus trabeculatus (Gorka) Reinhardt and Gorka, 1967

\author{
APPENDIX B \\ Systematic Paleontology \\ Kingdom PLANTAE \\ Division CHRYSOPHYTA \\ Class COCCOLITHOPHYCEAE Rothmaler, 1951 \\ Order DISCOASTERACEAE Tan, 1927 \\ Family DISCOASTERACEAE Tan, 1927 \\ Genus DISCOASTER Tan, 1927
}

Discoaster bergenii $\mathrm{n} . \mathrm{sp}$.

(Pl. 1, Fig. 15)

Discoaster sp. cf. D. berggrenii (Bukry) Bergen, 1984, p. 431, Pl. 1, Fig. 6.

Description. This small (5-9 $\mu \mathrm{m})$, symmetric, five-rayed discoaster has rays with the free length less than one-half the length of the central area. A prominent stellate knob entirely fills or extends beyond the central area.

Remarks. Discoaster bergenii is distinguished from $D$. berggrenii (Bukry, 1971) by its shorter rays, with free lengths less than or equal to one-half the length of the central area. The central stellate knob is distinctly developed and fills or extends beyond the central area of the asterolith. Discoaster bergenii is also generally smaller in size $(5-9 \mu \mathrm{m})$ than $D$. berggrenii $(8-13 \mu \mathrm{m})$.

Stratigraphic range. This species occurs with Discoaster berggrenii in the Discoaster calcaris Zone (NN10) in ODP Hole 646B and does not occur in situ with Discoaster quinqueramus. Its lowest occurrence below the lowest occurrence of Discoaster berggrenii is recorded by Bergen (1984) in DSDP Holes 541 and 542.

Holotype. The designated holotype is illustrated in Bergen (1984), Pl. 1, Fig. 6, Sample 78A-541-28-6, 54-55 cm.

Type locality. DSDP Holes 541 and 542 in the Atlantic Ocean near the Lesser Antilles margin.

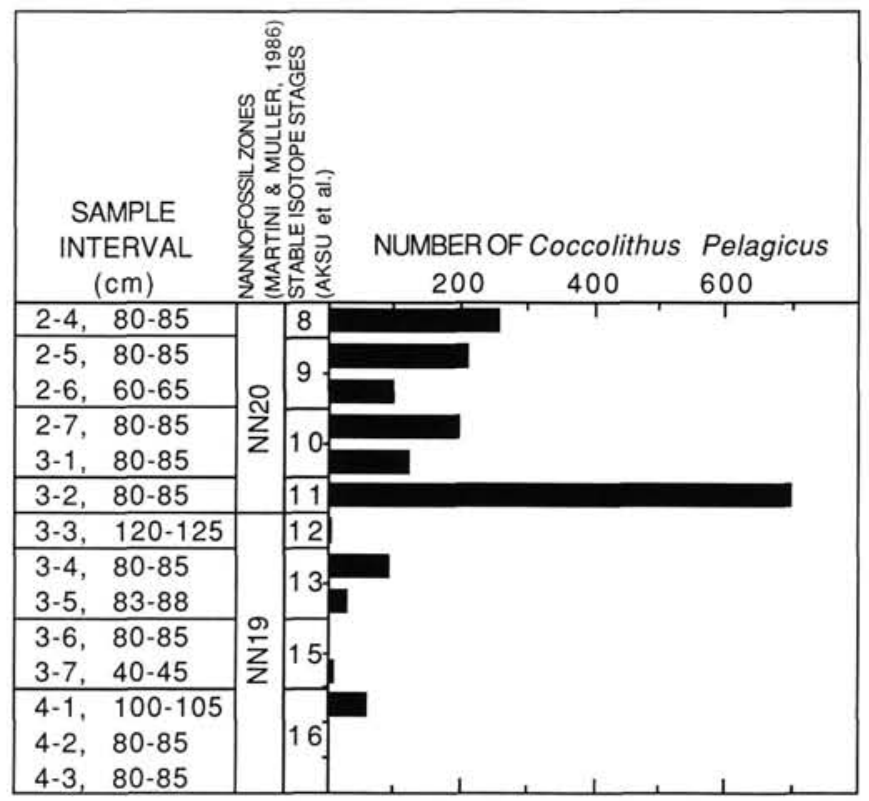

Figure 4. Correlation of nannofossil zones, stable-isotope stages (Aksu et al., this volume) and actual numbers of individuals of Coccolithus pelagicus observed in 100 fields of view at $1250 \times$ magnification in selected samples from Hole 647B. 


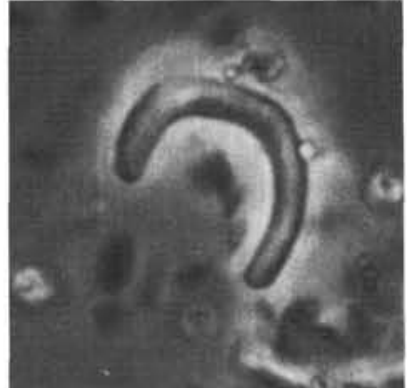

1

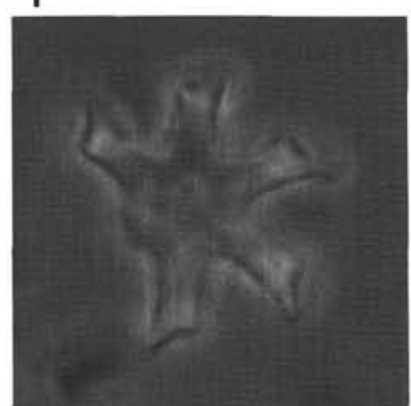

5

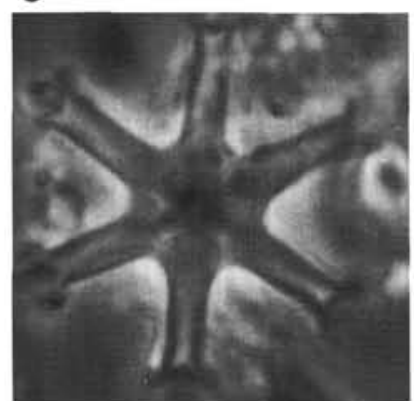

9

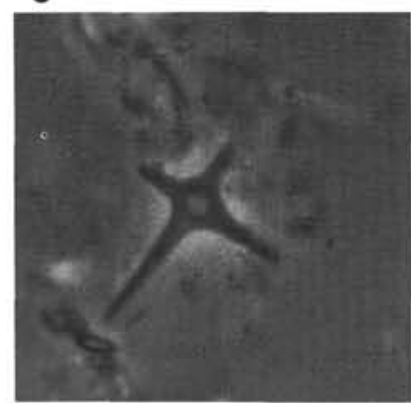

13

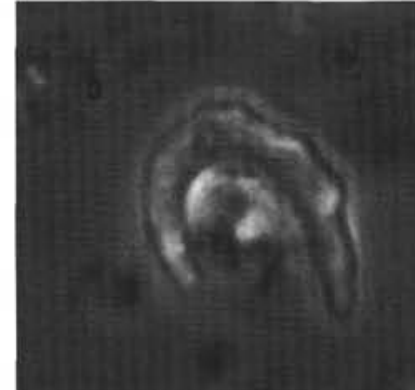

2

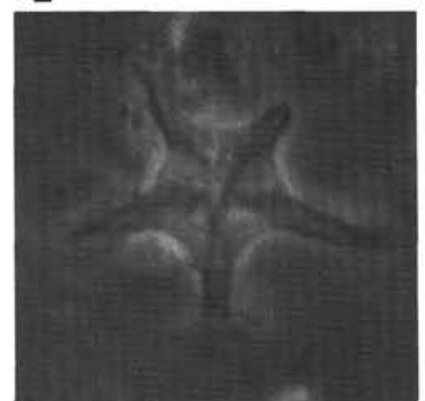

6

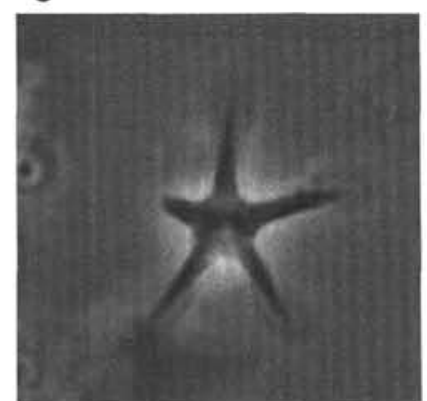

10

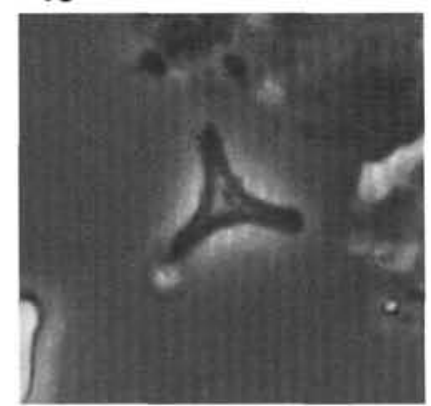

14

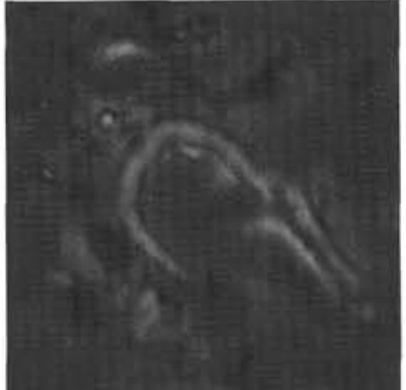

3

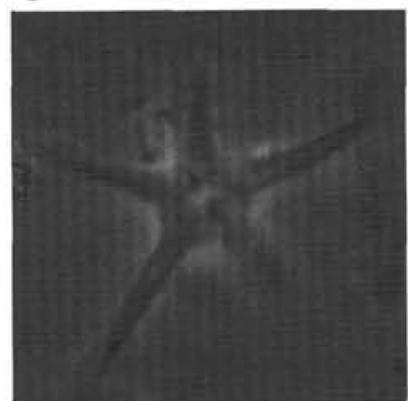

7

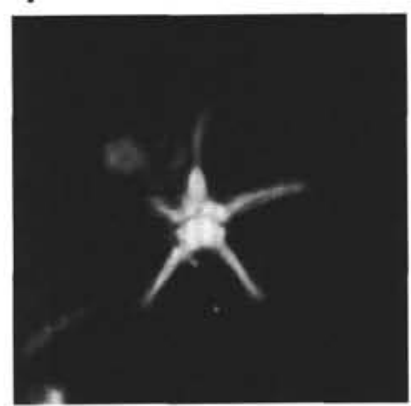

11

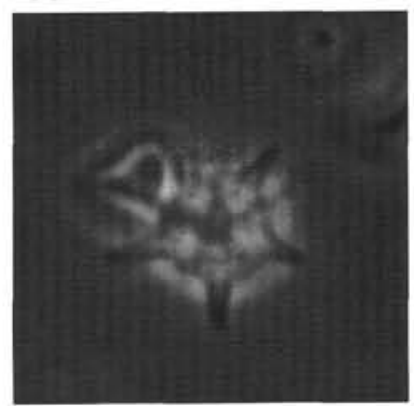

15

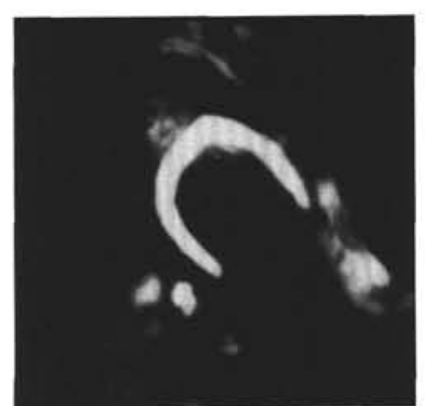

4

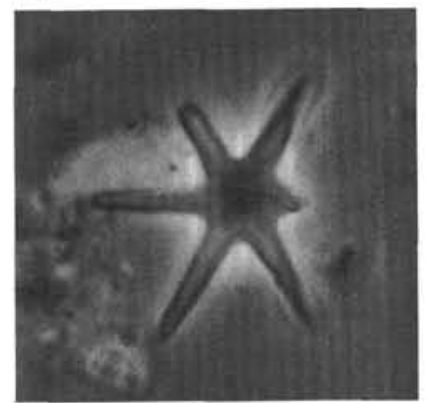

8

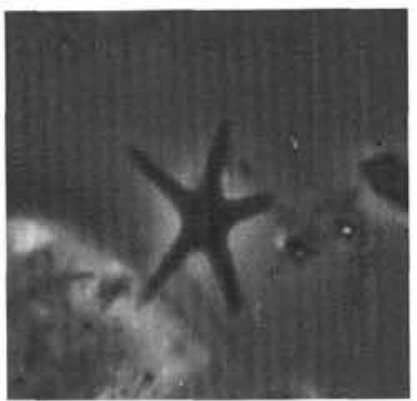

12

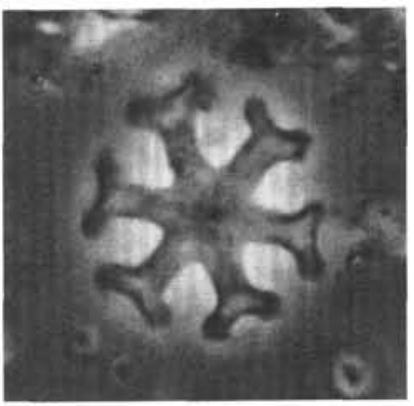

16

Plate 1. Late Miocene to Pliocene nannofossils from Hole 646B. 1. Amaurolithus primus, Section 105-646B-73X, CC, 3000 $\times$. 2-4. Ceratolithus cristatus; 2) Section 105-646B-44X, CC, 3000× ; 3-4) Sample 105-646B-46X-2, 25-27 cm, 2500×. 5. Discoaster loeblichii, Section 105-646B$79 \mathrm{X}, \mathrm{CC}, 2500 \times$. 6. Discoaster berggrenii, Sample 105-646B-79X-1, 24-26 cm, 2500× . 7. Discoaster quinqueramus, Sample 105-646B-75X-1, $108-110 \mathrm{~cm}, 2500 \times$. 8. Discoaster brouweri, Sample 105-646B-43X-3, 93-95 cm, 2500×. 9. Discoaster surculus, Sample 105-646B-23X-1, 62-64 $\mathrm{cm}, 2500 \times .10$ and 11. Discoaster pentaradiatus, Sample 105-646B-30X-2, $56-58 \mathrm{~cm}, 2500 \times$. 12. Discoaster asymmetricus, Sample 105-646B$30 X-2,56-58 \mathrm{~cm}, 2500 \times$. 13. Discoaster tamalis, Sample 105-646B-30X-2, 56-58 cm, 2500×. 14. Discoaster triradiatus, Sample 105-646B$30 \mathrm{X}-2,56-58 \mathrm{~cm}, 2500 \times$. 15. Discoaster bergenii n. sp., Section 105-646B-79-CC, $2500 \times$. 16. Discoaster pansus, Sample 105-646B-75X-1, $108-110 \mathrm{~cm}, 2500 \times$. 


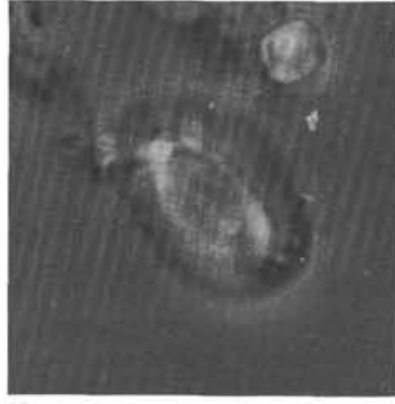

1

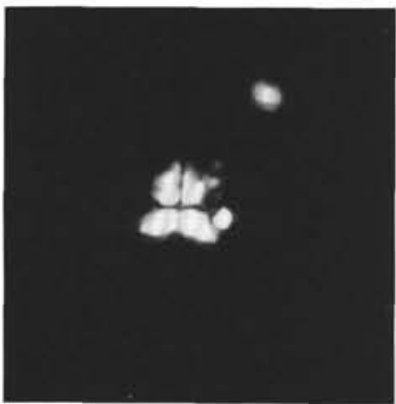

5

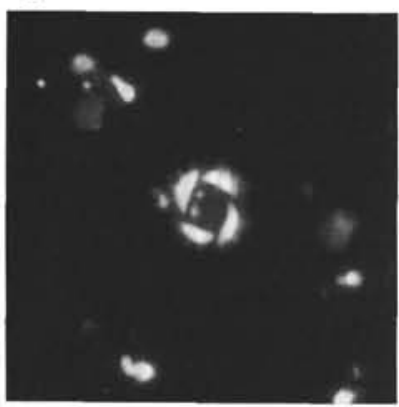

9

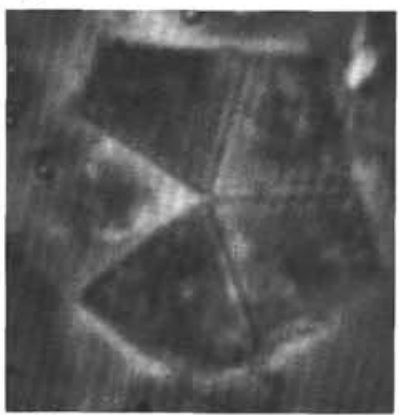

13

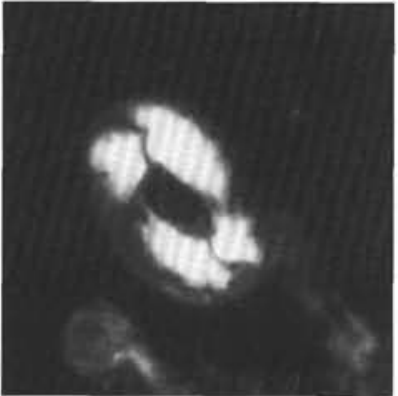

2

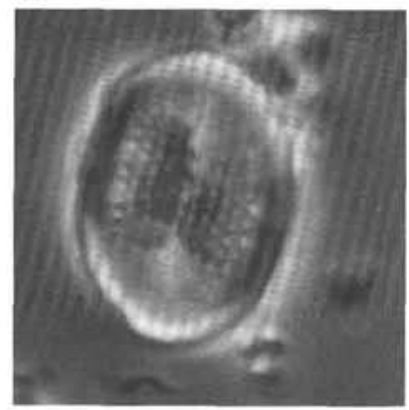

6

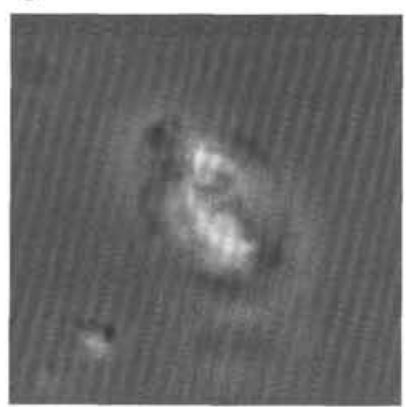

10

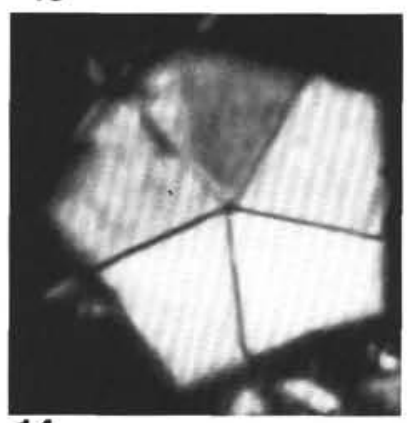

14

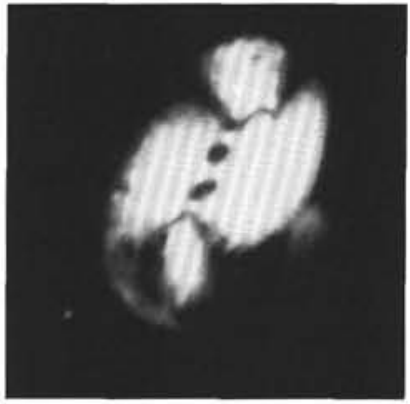

3

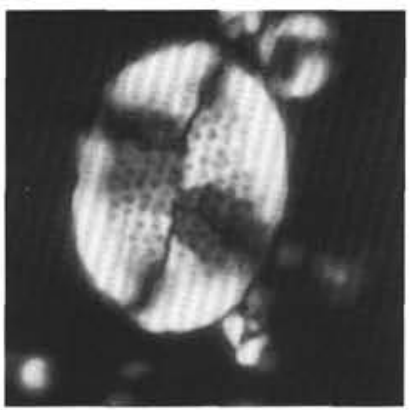

7

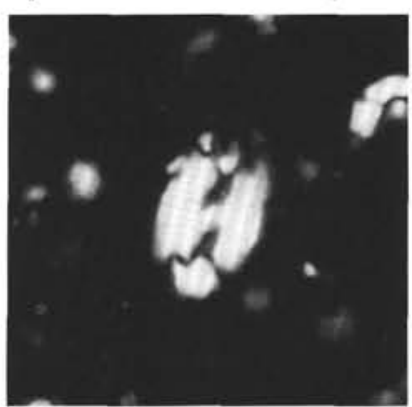

11

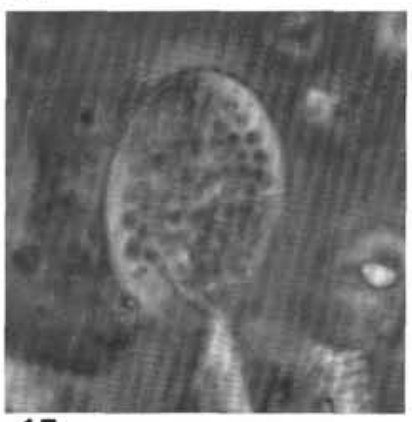

15

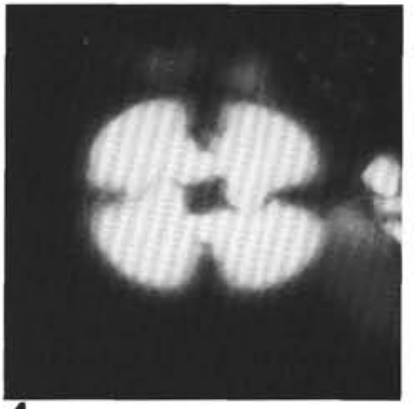

4

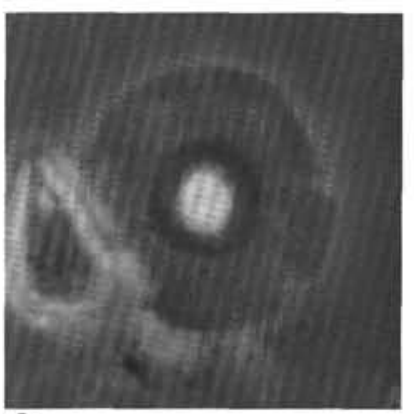

8

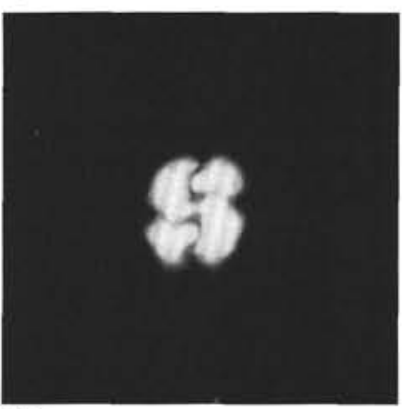

12

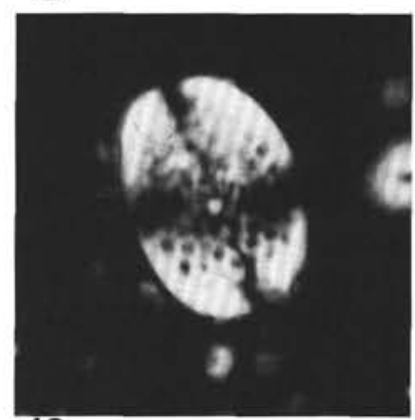

16

Plate 2. Early Miocene nannofossil from Hole 645E and late Miocene to Pleistocene nannofossils from Hole 646B. 1 and 2. Helicosphaera ampliaperta, Section 105-645E-70X, CC, 2500×. 3. Helicosphaera carteri, Sample 105-646B-39X-5, 39-41 cm, 3000×. 4. Reticulofenestra pseudoumbilica, Section 105-646B-53X, CC, $2500 \times$. 5. Sphenolithus abies, Sample 105-646B-49X-2, 118-120 cm, $2500 \times$. 6 and 7. Pontosphaera japonica, Sample 105-646B-13H-1, 34-36 cm, 2500 × . 8. Calcidiscus macintyrei, Sample 105-646B-30X-2, 56-58 cm, 2500×. 9. Pseudoemiliania lacunosa, Sample 105-646B-13H-1, 34-36 cm, 2500 × 10 and 11. Helicosphaera sellii; 10) Sample 105-646B-13H-1, 34-36 cm, 2500 ×; 11) Sample 105-646B$26 \mathrm{X}-1,76-78 \mathrm{~cm}, 2500 \times$. 12. Gephyrocapsa oceanica, Sample 105-646B-12H-5, $92-94 \mathrm{~cm}, 2500 \times$. 13 and 14. Braarudosphaera bigelowii, Section 105-646B-44X, CC, 3000x. 15 and 16. Pontosphaera discopora, Sample 105-646B-30X-2, 56-58 cm, $2500 \times$. 